\title{
Analysis of the hydrographic conditions and cyst beds in the San Jorge Gulf, Argentina, that favor dinoflagellate population development including toxigenic species and their toxins
}

\author{
Bernd Krock $^{\mathrm{a}, 1}$, C. Marcela Borel ${ }^{\mathrm{b}, \mathrm{e}}$, Facundo Barrera ${ }^{\mathrm{c}, \mathrm{e}}$, Urban Tillmann ${ }^{\mathrm{a}}$, Elena Fabro ${ }^{\mathrm{d}, \mathrm{e}}$, \\ Gastón O. Almandoz ${ }^{\mathrm{d}, \mathrm{e}}$, Martha Ferrario ${ }^{\mathrm{d}, \mathrm{e}}$, John E. Garzón Cardona ${ }^{\mathrm{ce}}$, Boris P. Koch ${ }^{\mathrm{a}, \mathrm{f}}$, \\ Cecilia Alonso ${ }^{g}$, Rubén Lara ${ }^{\mathrm{c}, \mathrm{e}}$ \\ a Alfred Wegener Institut-Helmholtz Zentrum für Polar- und Meeresforschung, Chemische Ökologie, Am Handelshafen 12, 27570 Bremerhaven, Germany \\ b Instituto Geológico del Sur (CONICET-Universidad Nacional del Sur), Departamento de Geología, Laboratorio de Palinología, San Juan 670,8000 Bahía Blanca, Argentina \\ c Instituto Argentino de Oceanografí, Biogeoquímica Marina, IADO-CONICET, La Carrindanga km 7,5 c.c. 804, B8000FWB Bahía Blanca, Argentina \\ d División Ficología, Facultad de Ciencias Naturales y Museo, Universidad Nacional de La Plata, Paseo del Bosque s/n, 1900 La Plata, Argentina \\ e CONICET, Consejo Nacional de Investigaciones Científicas Técnicas, Av. Rivadavia 1917, 1033 Buenos Aires, Argentina \\ ${ }^{\mathrm{f}}$ University of Applied Sciences, An der Karlstadt 8, D-27568 Bremerhaven, Germany \\ g Centro Universitario Regional Este, Universidad de la República, Rincón s/n, CP27000 Rocha, Uruguay
}

\section{A R T I C L E I N F O}

\section{Article history:}

Received 22 October 2014

Received in revised form 21 January 2015

Accepted 26 January 2015

Available online 30 January 2015

\section{Keywords:}

Coastal water masses

Southwest Atlantic

Planktonic community

Toxins

Alexandrium tamarense

Protoceratium reticulatum

LC-MS/MS

Dinoflagellate bloom

Dinoflagellate cysts

\begin{abstract}
A B S T R A C T
The overlay of cooler nutrient enriched Beagle-Magellan water with warmer nutrient depleted shelf water and a strong stratification of the water column in the San Jorge Gulf region, Argentina, coincided with relatively high dinoflagellate abundances in April 2012, up to 34,000 cells $\mathrm{L}^{-1}$. This dinoflagellate proliferation was dominated by Ceratium spp., but environmental conditions also favored to a lesser amount the occurrence of toxigenic dinoflagellates, such as Alexandrium tamarense and Protoceratium reticulatum, whose toxins were hardly detected in any other areas along the expedition transect of the $R / V$ Puerto Deseado between 38 and $56^{\circ} \mathrm{S}$ (Ushuaia-Mar del Plata) in March/April 2012. Generally vegetative cells of A. tamarense and P. reticulatum co-occurred with their respective phycotoxins in the water column and their cysts in the upper sediment layers. Two strains of A. tamarense were isolated from the bloom sample and morphologically characterized. Their PSP toxin profiles consisted of $\mathrm{C} 1 / 2$, gonyautoxins $1 / 4$ and to a lesser amount of neosaxitoxin and confirmed earlier data from this region. The ratios between autotrophic picoplankton and heterotrophic bacteria were higher in shelf waters in the north than in Beagle-Magellan waters in the south of San Jorge Gulf.
\end{abstract}

(c) 2015 Elsevier B.V. All rights reserved.

\section{Introduction}

The Southwest Atlantic is well known for its high primary production and therefore presents a very important region for fisheries and seafood production (Bertolotti et al.;, 1996; Lutz et al., 2010). Zones of highest productivity are upwelling areas along the South American Continental Shelf Edge (Garcia et al., 2008; Romero et al., 2006), but also frontal zones, where current systems with different water masses converge, such as the Brazil Current and the Malvinas/Falkland Current (Brandini et al., 2000; Piola et al., 2010, 2013). In addition, there are smaller local frontal systems in deeper bays and gulfs along the arid

\footnotetext{
E-mail address: bernd.krock@awi.de (B. Krock).
}

1 Tel.: + 494714831 2055; fax: + 4947148311425 .
Patagonian coastline. These front systems result from isolated waters that are formed by interplay of high evaporation during summer, the shelf current systems and riverine inputs (Acha et al., 2004; Rivas and Pisoni, 2010). Current circulation suggests that tides, wind and bottom topography, for instance the ridge at the mouth of the San Jorge Gulf (SJG), are the main local forcing mechanisms in the Patagonian gulfs (Tonini et al., 2006; Palma et al., 2008; Matano et al., 2010). These hydrodynamic properties lead to distinct water masses characterized by high primary production. Among the phytoplankton species proliferating in these high productive areas there are also harmful algal taxa. Harmful algal blooms of the toxic marine dinoflagellates Alexandrium tamarense, Alexandrium catenella and Gymnodinium catenatum, which cause the neurotoxic paralytic shellfish poisoning (PSP), are a recurrent phenomenon along the Argentinean coast (Carreto et al., 1985, 1998a,b, 2008; Esteves et al., 1992; Santinelli et al., 2002). Toxic diarrhetic 
shellfish poisoning (DSP) episodes caused by Dinophysis species have been also reported (Sar et al., 2010, 2012), as well as the production of domoic acid (DA) by Pseudo-nitzschia species under field and culture conditions (Montoya et al., 2006; Negri et al., 2004; Sastre et al., 2007). In contrast, little is known about the occurrence of pectenotoxins (PTXs) and yessotoxins (YTXs). The most recently observed shellfish poisoning syndrome is azaspiracid shellfish poisoning (AZP), first reported in Europe in 1996 and unexplored on the Argentinean shelf. Except for the amnesic shellfish poisoning (ASP), which is produced by several species of the diatom genus Pseudo-nitzschia, all other shellfish poisoning syndromes are caused by dinoflagellates.

Dinoflagellates are biflagellate eukaryotic single-celled organisms that in the most prevalent stage (haploid motile) can reproduce asexually by binary fission. Beyond this relatively simple mode of reproduction, many extant free-living species are known to have a more complex life cycle producing, at times, vegetative or resting cysts. Resting cysts involve a usually obligatory period of dormancy (in contrast to temporary cysts) and commonly result from sexual fusion. The resting cysts eventually sink to the sea floor and remain dormant. The duration of cyst dormancy varies among species and ranges from hours to days or months (Figueroa et al., 2006; Hallegraeff et al., 1998; Kremp and Anderson, 2000). Cyst dormancy is an important stage in the life cycle of dinoflagellates and determines bloom seasonality. However, the relationship between this endogenous (genetic) clock and seasonality is not well understood (Bravo and Figueroa, 2014). Motile dinoflagellates and even temporary cysts are often quickly degraded by bacterial action after death. In contrast, the resting cyst wall is composed of a highly resistant organic material (dinosporin), or of calcium carbonate or rarely, silica. Cysts are protective and usually permit the protoplasm to survive adverse conditions and can remain viable many years after burial and sampling of the sediments (McQuoid et al., 2002; Ribeiro et al., 2011). Excystment, i.e. the release of motile cells can occur when the dormancy is over. Cysts enter in quiescence and when environmental conditions are appropriate, excystment is triggered (Warns et al., 2012). In laboratory experiments germination can be triggered by temperature, light availability, oxygen concentration and endogenous rhythms (Matthiessen et al., 2005 and literature therein). About 200 living marine dinoflagellates, including a number of harmful species, are known to produce organic-walled dinoflagellate cysts ("dinocysts") which are even preserved in conditions in which calcareous (coccoliths, foraminiferal tests) and siliceous (diatom frustules, radiolarian skeletons) microplankton remains are prone to dissolution (De Vernal and Marret, 2007). Thus, the study of the dinocysts recovered from modern sediments allows to record the dinoflagellate species even in times when the motile vegetative stage of the species are absent in the water column. Furthermore, the information on the distribution and abundance of dinocysts in sediments is essential to understand the ecology and dynamics of dinoflagellate blooms (Blackburn et al., 1989; Dale, 2001; Genovesi-Giunti et al., 2006; Matsuoka and Fukuyo, 2000). Areas with the highest concentrations of dinocysts of potentially toxic species are considered zones of risk for the initiation of new planktonic populations and future blooms of these microalgae. Studies of dinocysts recovered from surface sediments of the Southwest Atlantic are scarce. Offshore the Río de la Plata a pioneer dinocyst record was obtained in a NW-SE transect $\left(36-39^{\circ} \mathrm{S}\right)$ between 500 and $5000 \mathrm{~m}$ depth (Wall et al., 1977). Other records are available from the northern Argentine Shelf (Akselman, 1999; Borel et al., 2012) and only two studies exist from the Patagonian Shelf (Akselman, 1987; Orozco and Carreto, 1989).

In order to study the occurrence of harmful microalgae and their toxins in the water column and dinocysts in modern surface sediments along the Argentine Continental Shelf, we conducted an oceanographic expedition with the $R / V$ Puerto Deseado in March/April 2012. In the course of this expedition, we detected high concentrations of dinoflagellates and the occurrence of toxigenic species in the SGJ area $\left(45-47^{\circ} \mathrm{S}\right)$ and related it to the physicochemical characteristics of the surrounding environment.

\section{Methods}

\subsection{Study sites and sampling}

During the austral autumn, from March 27th to April 14th 2012, plankton, surface water and sediment samples were collected on board $R / V$ Puerto Deseado during the expedition "Patagonia Austral 2012". The sampling stations covered a variety of geographical areas at 48 stations along the Argentinean coast. The transect from $\sim 56^{\circ} \mathrm{S}$ (station I1) to $38^{\circ} \mathrm{S}$ (station I52) embraced $18^{\circ}$ of latitude with an average sampling resolution of about 50' (Fig. 1). The San Jorge Gulf transect (April 9th to 11th) consisted of six stations (S40, C43, C45, I44, C43N, P45B, Figs. 1A and 2A).

At all stations continuous profiles of temperature and salinity (CTD) were recorded. A vertical net tow was conducted at each station through the upper $20 \mathrm{~m}$ of the water column using a $20 \mu \mathrm{m}$-mesh Nitex plankton net. In addition, samples were collected using a Niskin bottle for nutrients analysis, pigments and quantitative plankton determination. The samples were grouped according to their oceanographic characterization (see below \& Fig. 4). In the SJG samples were grouped into surface $(10 \mathrm{~m})$ and deep water samples (>50 m; Table 1$)$. Surface sediment samples were obtained from the top centimeter of box coring. All samples were kept in dark and cool $\left(4{ }^{\circ} \mathrm{C},-20{ }^{\circ} \mathrm{C}\right.$ or $-80{ }^{\circ} \mathrm{C}$, as appropriate) conditions to preserve the cell integrity, stability of chlorophyll and nutrients, and prevent cyst germination (Matsuoka and Fukuyo, 2000).

\subsection{Oceanographic variables and data processing}

Data on temperature, salinity, and water depth were obtained using a CTD (Sea Bird model 911 plus with General Oceanic rosette) and calibrated with a final precision of 0.05 in salinity and $0.02{ }^{\circ} \mathrm{C}$ in temperature. All parameters were processed and displayed using Ocean Data View Software (ODV-version 4.6, Schlitzer, 2010). To determine the location of ocean fronts, the Simpson's stability index was estimated at each station (Simpson, 1981). The Simpson parameter, a measure of the mechanical work required for vertical mixing of the water column, is defined as:

$\Phi=\frac{g}{h} \int_{-h}^{0}(\rho-\rho 0) \cdot z \cdot d z$

where $g$ is the gravity, $h$ is the depth, and $\rho o$ is the mean density of the water column. Small values of $\Phi$ indicate poorly stratified waters while high values are associated with stratified waters (Simpson, 1981). A value of $\sim 40 \mathrm{~J} \mathrm{~m}^{-3}$ was selected as the limit between homogeneous and stratified waters (Bianchi et al., 2005; Martos and Sánchez, 1997; Sabatini et al., 2000, 2004). The Brunt-Väisäla $\left(\mathrm{N}^{2}\right)$ was calculated as a measure of stratification variability of the water column, according to the equation:

$N^{2}=-\frac{g}{\rho_{o}} \frac{\partial \rho}{\partial z}$

where $g=$ gravity of the Earth $\left(9.8 \mathrm{~m}^{2} \mathrm{~s}^{-1}\right), \rho=$ density of water, $z=$ depth.

\subsection{Nutrient and pigment analyses}

One liter of surface seawater was filtered (max. 300 mbar) using two precombusted $\left(4 \mathrm{~h}, 450^{\circ} \mathrm{C}\right)$ glass fiber filters $(\sim 0.7 \mu \mathrm{m}, \mathrm{GF} / \mathrm{F}$, Whatman $)$. From the first $0.5 \mathrm{~L}, 40 \mathrm{~mL}$ aliquots were transferred into acid-precleaned HDPE bottles, poisoned with $120 \mu \mathrm{L}$ of $\mathrm{HgCl}_{2}\left(35 \mathrm{~g} \mathrm{~L}^{-1}\right)$ and stored at $4{ }^{\circ} \mathrm{C}$ for later nutrient analyses (Kattner, 1999). Duplicate filtrates for DOC and TDN determination were adjusted after filtration 

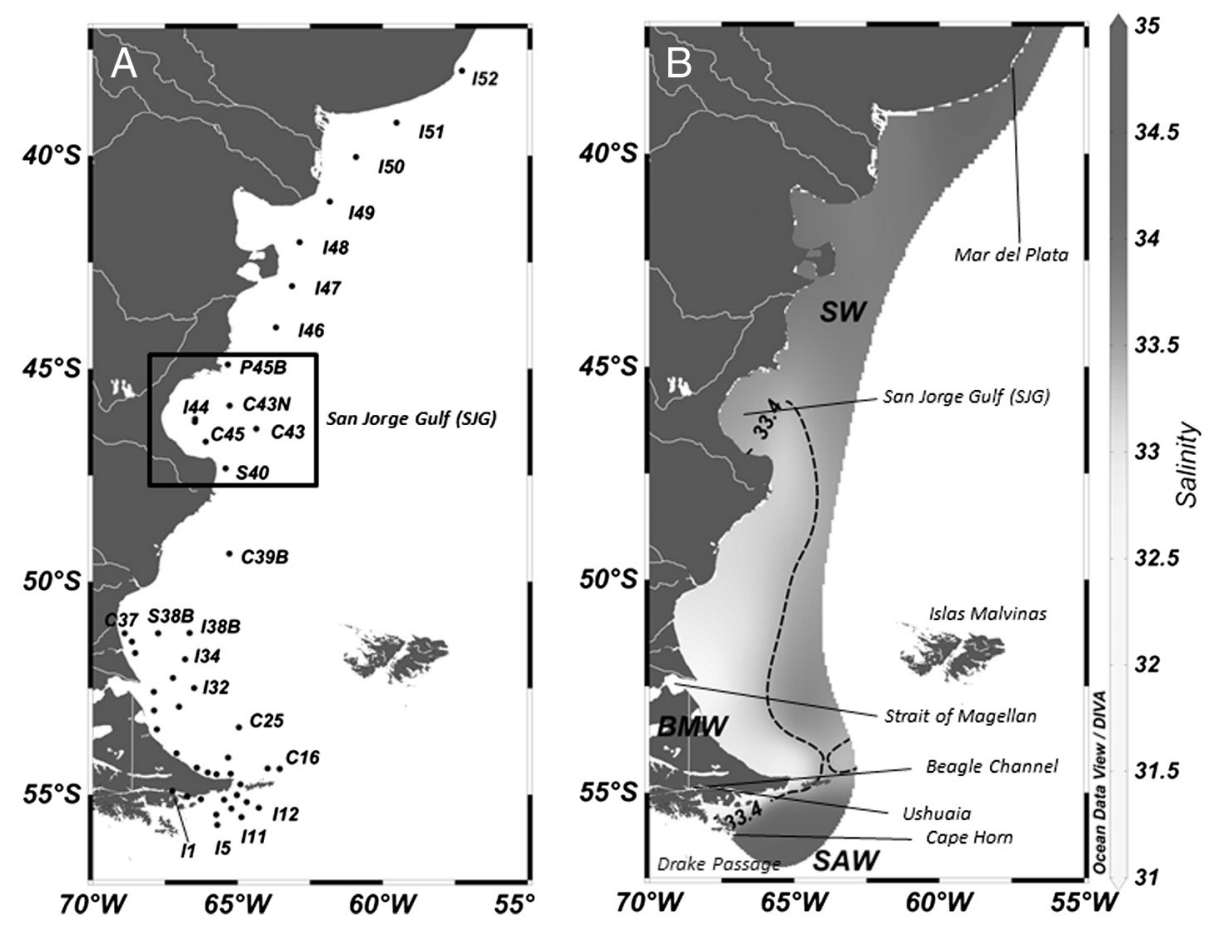

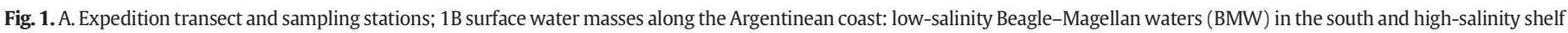
waters (SW) in the north; SAW = Subantarctic Waters.

to $\mathrm{pH}=2$ (with $\mathrm{H}_{3} \mathrm{PO}_{4}$ ) in $10 \mathrm{~mL}$ precombusted glass ampoules. These and the two filters with seston from $0.5 \mathrm{~L}$ each for pigment determination, were kept frozen $\left(-20^{\circ} \mathrm{C}\right)$ in the dark until further processing on land. Nutrients were measured using an autoanalyzer (Evolution III, Alliance Instruments) and standard seawater methods (Kattner and Becker, 1991).

Dissolved organic carbon (DOC) and total dissolved nitrogen (TDN) were determined by high temperature catalytic oxidation and subsequent non-dispersive infrared spectroscopy and chemoluminescence detection (TOC-VCPN, Shimadzu). Final DOC and TDN concentrations are average values of triplicate measurements on replicate samples. If the standard variation or the coefficient of variation exceeded $0.1 \mu \mathrm{M}$ or $1 \%$, respectively, up to 2 additional analyses were performed and outliers were eliminated. After each batch of five samples one reference standard (DOC-DSR, Hansell Research Lab, University of Miami, US), one ultrapure water blank and one potassium hydrogen phthalate standard were measured. The limit of detection $(3 \times$ standard deviation $(\sigma)$ of the blank) and quantitation ( $9 \sigma$ of the blank) was 7 and $21 \mu \mathrm{M} \mathrm{C}$, respectively. The accuracy was $\pm 5 \%$.

Pigment extraction on duplicate filter samples was performed in $10 \mathrm{~mL} 90 \%$ acetone during $24 \mathrm{~h}$ at $4{ }^{\circ} \mathrm{C}$ in darkness. Chlorophyll-a and phaeopigments were quantified by fluorometry, and concentrations were estimated according to Holm-Hansen et al. (1965) equations. We used a standard of pure chlorophyll-a (Anacystis nidulans) and a Shimadzu RF-5301 fluorometer at $\lambda_{\mathrm{Ex}} / \lambda_{\mathrm{Em}}: 460 / 671 \mathrm{~nm}$. The correction was made for phaeopigments by acidification with $\mathrm{HCl}(0.1 \mathrm{~N})$.

Satellite data were retrieved from the Giovanni Ocean Color Radiometry 8-day (6-13 April, 2012) temporal resolution products from MODIS-Aqua 4-km database (http://disc.sci.gsfc.nasa.gov/giovanni) on a $0.1^{\circ}$ resolution. Chlorophyll-a (chl-a) concentrations derived from satellite images were retrieved from the SDN spreadsheet and plotted with the DIVA gridding option (Ocean Data View, version 4.6).

\subsection{Size fractionation, cell counts and species identification}

The sample volume of each net haul was topped up to $1 \mathrm{~L}$ with $0.2 \mu \mathrm{m}$ filtered sea water. An aliquot of $20 \mathrm{~mL}$ was fixed with $400 \mu \mathrm{L}$
Lugol's solution for species determination and enumeration. The rest was sequentially filtered through Nitex meshes of 200, 50 and $20 \mu \mathrm{m}$ by gravity filtration and split into aliquots for extraction of lipophilic and hydrophilic toxins. The aliquots of suspended plankton size fractions were pelleted by centrifugation for subsequent toxin analysis. In addition, plankton samples were collected at 3 and $10 \mathrm{~m}$ depth from Niskin bottles. $3.5 \mathrm{~L}$ of each depth were mixed and $100 \mathrm{~mL}$ of the mixed water was treated with $2 \mathrm{~mL}$ of Lugol's solution for species identification and enumeration. The rest of the samples were pre-screened through a $20 \mu \mathrm{m}$ mesh-size Nitex sieve and the filtrate was split in two 3-L aliquots. Each aliquot was then filtered under gentle vacuum through $3 \mu \mathrm{m}$ pore-size polycarbonate filters (Millipore, Eschborn, Germany). Dry filters were placed individually in $50 \mathrm{~mL}$ centrifuge tubes (Sarstedt, Nümbrecht, Germany) and stored at $-20{ }^{\circ} \mathrm{C}$ until analysis.

For phytoplankton quantitative estimations of Niskin bottle samples, cells were enumerated with a phase contrast Leica DMIL LED inverted microscope according to the procedures described by Utermöhl (1958). Subsamples of $50 \mathrm{~mL}$ were settled for $24 \mathrm{~h}$ in a composite sedimentation chamber. For the analysis of net samples, subsamples were counted in Sedgewick-Rafter chambers under the same microscope according to LeGresley and McDermott (2010). The whole chamber bottom was scanned at $200 \times$ magnification. Densities are expressed as cells in net tow (cells $\mathrm{NT}^{-1}$ ). Additional qualitative observations of dinoflagellates were done by UV epifluorescence microscopy (Leica DM 2500) of thecal plates stained with Calcofluor according to Fritz and Triemer (1985). For diatom frustules observation, organic material was removed from net subsamples using sodium hypochlorite and mounted on permanent slides as described in Almandoz et al. (2011). Additionally, clean material was filtered onto $0.2 \mu \mathrm{m}$ polyamide filters, sputter coated with Au-Pd and examined by scanning electron microscopy (Jeol JSM-6360 LV) to confirm the identity of Pseudo-nitzschia species.

For picoplankton abundance determination, $3 \mathrm{~mL}$ of surface seawater sample were preserved with $1 \%$ paraformaldehyde $+0.05 \%$ glutaraldehyde (final concentration), frozen and stored at $-20^{\circ} \mathrm{C}$. The samples were later thawed, stained with SYBR-Green I (SYBR-I, 1:30 dilution of commercial stock; Invitrogen, USA; $1_{\mathrm{ex}} \lambda 495 \mathrm{~nm}, 1_{\mathrm{em}} \lambda 525 \mathrm{~nm}$ ) diluted in dimethyl sulfoxide (DMSO, Merck, Germany) (Marie et al., 2005). Ten 

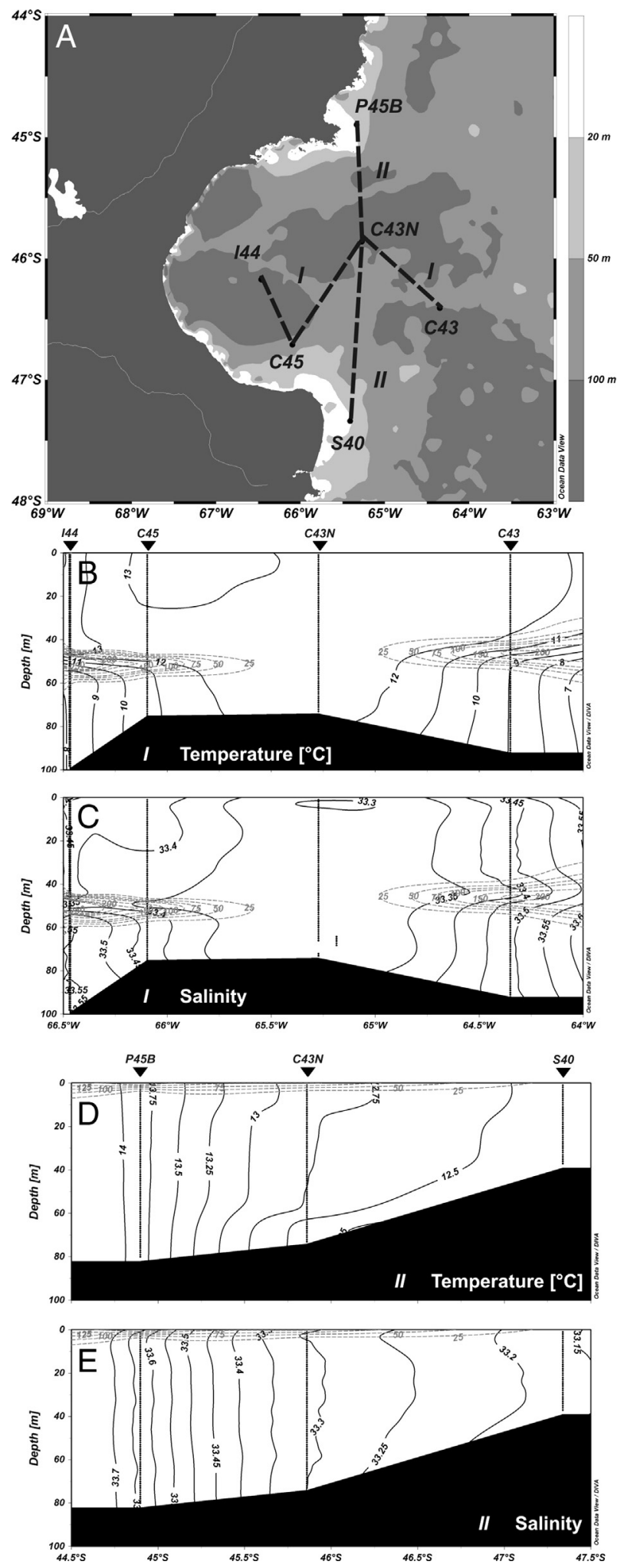

Fig. 2. A. Geographic location of SJG transects shown in 2B to E. Fig. 2B Temperature gradient of the W-E (I) transect and Fig. 2CW-E transect (I) showing the superimposition of BMW by SW in the inner SJG and outside the SJG. Fig. 2D Temperature gradients of the $\mathrm{N}-\mathrm{S}$ transect (II) and Fig. 2E salinity gradient of the N-S transect (II) showing the transition of BMW and SW. (II). Brunt-Vaisala Frequency in dashed gray lines $\left(\mathrm{cycl} \mathrm{h}^{-1}\right)$.

microliters of fluorochrome was added to $1 \mathrm{~mL}$ of bacterial sample. Samples were incubated in the dark for $15 \mathrm{~min}$ at room temperature. Flow Cytometry analyses were performed with an Apogee-A40 flow cytometer (Apogee Flow Systems, UK) equipped with an argon laser
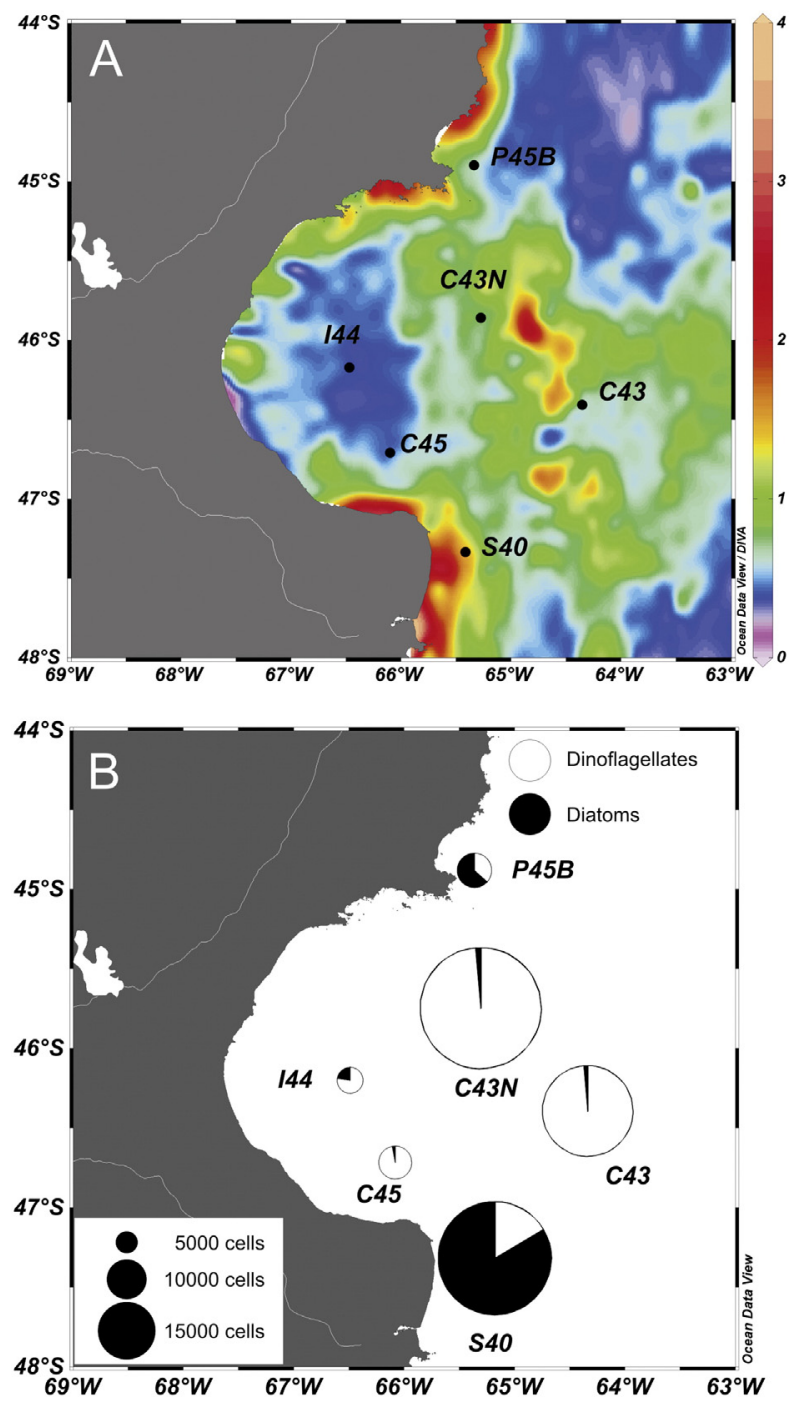

Fig. 3. A. Plot based on satellite data of the SJG indicating mean chl-a abundances between April 6th and April 13th 2012; 3B: phytoplankton abundance (cells $\mathrm{L}^{-1}$; circle diameter are proportional to cell abundances) and composition in the SJG in mixed Niskin bottle samples from 3 and $10 \mathrm{~m}$ depth.

(488 nm). Cells were counted following Marie et al. (2005). Briefly, heterotrophic bacteria (HB) were detected by their signature in a plot of side scatter (SSC) versus green fluorescence (FL1). Autotrophic picoplankton (AP) were detected by direct fluorescence in a plot of SSC versus red fluorescence (FL3).

\subsection{Isolation of A. tamarense}

At station C43, $100 \mathrm{~mL}$ of seawater from $3 \mathrm{~m}$ depth was filled into a polyethylene flask and kept at $4{ }^{\circ} \mathrm{C}$ in the dark until inspection in the laboratory eleven days after sampling. Single $A$. tamarense cells were isolated from this sample under a stereomicroscope (Olympus SZHILLD) by micropipette. The cells were transferred into individual wells of 96-well tissue culture plates (TPP, Trasadingen, Switzerland) containing $300 \mu \mathrm{L}$ of medium, prepared from $0.2 \mu \mathrm{m}$ sterile-filtered natural Antarctic seawater with $1 / 10$ of the original concentration of $\mathrm{K}$ medium (Keller et al., 1987). Isolated cells were then incubated at $15^{\circ} \mathrm{C}$ under artificial light at a photon flux density of $50 \mu \mathrm{mol}$ photons $\mathrm{m}^{-2} \mathrm{~s}^{-1}$ on a 16:8 light:dark (L:D) photocycle. After 3 to 4 weeks, two unialgal and clonal isolates (provisionally named $\mathrm{H} 5$ and $\mathrm{H} 7$ ) were transferred to polystyrene cell culture flasks each containing $50 \mathrm{~mL}$ of $1 / 2$ strength 


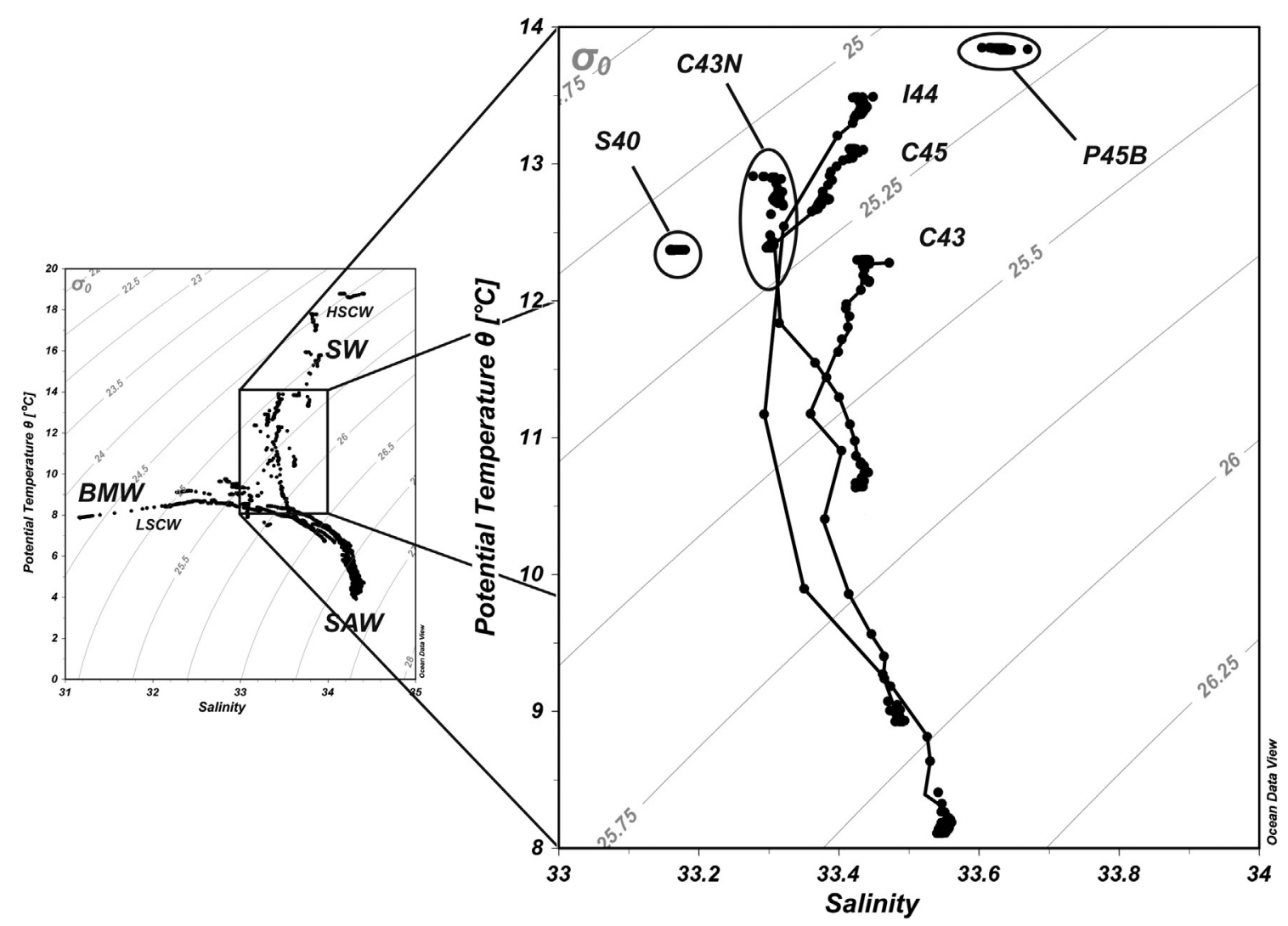

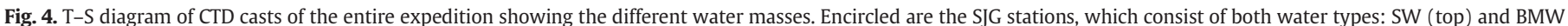

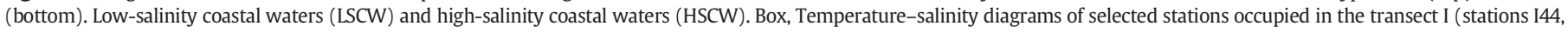
C45, C43N and C 43) and transect II (stations S40, C43N and P45B) (see Fig. 2).

$\mathrm{K}$ medium and were maintained thereafter under the same conditions as described.

For toxin analysis, one culture of each isolate was grown in $250 \mathrm{~mL}$ Erlenmeyer glass flasks at $15{ }^{\circ} \mathrm{C}$ under a photon flux density of $50 \mu \mathrm{mol} \mathrm{m}{ }^{-2} \mathrm{~s}^{-1}$ on a 16:8 h light:dark photocycle. Cell density was determined by settling lugol-fixed samples and counting $>800$ cells under an inverted microscope. Dense cultures (densities ranging from ca. 5000 (H5) to 10,000 (H7) cells per mL, and thus most probably representing late exponential phase) were harvested in $4 \times 50 \mathrm{~mL}$ in $50 \mathrm{~mL}$ centrifugation tubes by centrifugation (Eppendorf 5810R, Hamburg, Germany) at $3220 \times \mathrm{g}$ for $10 \mathrm{~min}$. All four pellets from one isolate were combined in a microtube and again centrifuged (Eppendorf 5415, 16,000 ×g, $5 \mathrm{~min}$ ) and stored frozen $\left(-20^{\circ} \mathrm{C}\right)$ until use.

Observation of live or fixed cells was carried out with a stereomicroscope (Olympus SZH-ILLD) and with an inverted microscope (Axiovert 200 M, Zeiss, Germany) equipped with epifluorescence and differential interference contrast optics. Light microscopic examination of the thecal plate tabulation was performed on formalin-fixed cells ( $1 \%$ final concentration) stained with calcofluor white (Fritz and Triemer, 1985).
Photographs were taken with a digital camera (Axiocam MRc5, Zeiss, Germany).

\subsection{Toxin extraction and determination}

Cell pellets from the plankton net tows and $A$. tamarense cultures were harvested by centrifugation $\left(3220 \times \mathrm{g}, 15 \mathrm{~min}\right.$ at $\left.4{ }^{\circ} \mathrm{C}\right)$, suspended in $500 \mu \mathrm{L}$ methanol for lipophilic toxins and $0.03 \mathrm{M}$ acetic acid for hydrophilic toxins, and subsequently transferred into a FastPrep tube containing $0.9 \mathrm{~g}$ of lysing matrix D (Thermo Savant, Illkirch, France). The samples were homogenized by reciprocal shaking at maximum speed $\left(6.5 \mathrm{~m} \mathrm{~s}^{-1}\right)$ for $45 \mathrm{~s}$ in a Bio101 FastPrep instrument (Thermo Savant, Illkirch, France). After homogenization, samples were centrifuged at $16,100 \times g$ at $4{ }^{\circ} \mathrm{C}$ for $15 \mathrm{~min}$. The supernatant was transferred to a spinfilter ( $0.45 \mu \mathrm{m}$ pore-size, Millipore Ultrafree, Eschborn, Germany) and centrifuged for $30 \mathrm{~s}$ at $800 \times \mathrm{g}$, followed by transfer to autosampler vials. The filtrates of the acetic acid extraction were analyzed for PSP toxins after separation of target analytes in reversed-phase mode by high-performance liquid chromatography with post-column derivatization and fluorescence detection (LC-FD), according to the method given

Table 1

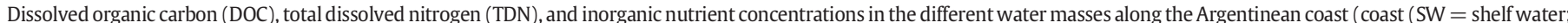

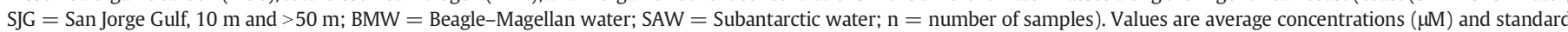
deviations are given.

\begin{tabular}{|c|c|c|c|c|c|c|c|c|}
\hline Water mass & $\mathrm{n}$ & $\begin{array}{l}\text { DOC } \\
{[\mu \mathrm{M}]}\end{array}$ & $\begin{array}{l}\text { TDN } \\
{[\mu \mathrm{M}]}\end{array}$ & $\begin{array}{l}\text { Nitrate } \\
{[\mu \mathrm{M}]}\end{array}$ & $\begin{array}{l}\text { Nitrite } \\
{[\mu \mathrm{M}]}\end{array}$ & $\begin{array}{l}\text { Silicate } \\
{[\mu \mathrm{M}]}\end{array}$ & $\begin{array}{l}\text { Phosphate } \\
{[\mu \mathrm{M}]}\end{array}$ & $\begin{array}{l}\text { Ammonium } \\
{[\mu \mathrm{M}]}\end{array}$ \\
\hline SW & 8 & $78 \pm 7$ & $7.0 \pm 3.6$ & $2.0 \pm 4.2$ & $0.0 \pm 0.0$ & $2.7 \pm 1.6$ & $0.8 \pm 0.2$ & $0.3 \pm 0.3$ \\
\hline SJG $10 \mathrm{~m}$ & 6 & $71 \pm 9$ & $7.1 \pm 3.6$ & $1.8 \pm 1.8$ & $0.1 \pm 0.1$ & $3.3 \pm 1.3$ & $0.6 \pm 0.2$ & $0.6 \pm 0.2$ \\
\hline $\mathrm{SJG}>50 \mathrm{~m}$ & 3 & $65 \pm 10$ & $22.7 \pm 1.7$ & $17.8 \pm 3.8$ & $0.1 \pm 0.1$ & $10.9 \pm 5.5$ & $1.7 \pm 0.4$ & $0.1 \pm 0.0$ \\
\hline SAW & 25 & $52 \pm 6$ & $22.3 \pm 3.7$ & $19.2 \pm 4.4$ & $0.2 \pm 0.1$ & $5.1 \pm 4.6$ & $1.3 \pm 0.2$ & $0.6 \pm 0.3$ \\
\hline BMW & 27 & $63 \pm 6$ & $17.1 \pm 3.5$ & $11.6 \pm 2.5$ & $0.3 \pm 0.2$ & $2.4 \pm 0.6$ & $1.0 \pm 0.1$ & $1.1 \pm 0.9$ \\
\hline
\end{tabular}


in Krock et al. (2007). Analysis of multiple lipophilic toxins in the methanolic extracts was performed by liquid chromatography coupled to tandem mass spectrometry (LC-MS/MS), as described in Krock et al. (2008).

For AZA analysis, polycarbonate filters with $20 \mu \mathrm{m}$ pre-screened samples from the rosette bottles were repeatedly rinsed with $1 \mathrm{~mL}$ methanol until complete decolouration of the filters. The methanolic extract was filtered through spin-filters as described above. AZA profiles were determined as previously described (Krock et al., 2009).

\subsection{Sediment analysis for dinocysts}

An aliquot (5-10 g wet weight) of the sediment sample from each station was sieved through $150 \mu \mathrm{m}$ and $10 \mu \mathrm{m}$ Nitex ${ }^{\circledR}$ screens to eliminate coarse sand, fine silt and clay. One calibrated tablet of Lycopodium clavatum (University of Lund, BATCH $\mathrm{N}^{\circ}$ 483216) containing 18,583 spores was added to each sample as an internal standard (Stockmarr, 1971 ) to allow for the calculation of concentrations in cysts $\mathrm{g}^{-1}$ sediment. The 10 to $150 \mu \mathrm{m}$ grain size fraction was treated with cold $10 \%$ hydrochloric acid $(\mathrm{HCl})$ to eliminate carbonates. A zinc chloride $\left(\mathrm{ZnCl}_{2}\right)$ solution adjusted to a density of $\rho=2.0 \mathrm{~g} \mathrm{~cm}^{-3}$ was used to separate the organic fraction based on a density gradient. Residues were sieved and collected on a 10- $\mu \mathrm{m}$ mesh and then mounted between slide and cover-slide in Kaiser gelatinized-glycerine (De Vernal et al., 1996).

Dinocysts were identified and counted using a transmitted-light microscope (Nikon Eclipse 600) at a magnification factor of $600 \times$ and $1000 \times$. The nomenclature of the dinocysts follows Fensome et al. (1993) and the taxonomy for the motile dinoflagellates was used. A minimum of 200 dinocysts was counted per sample. Using these counts, the abundance of each taxon and the concentration of total dinocysts per mass unit of wet sediment [ $\mathrm{g}]$ were determined.

Two cyst morphotypes of the genus Spiniferites are present (known as Spiniferites ramosus and Spiniferites mirabilis from the paleontological literature) and are grouped in this study as dinocysts of Gonyaulax aff. spinifera (following Head, 1996 and literature therein; Rochon et al., 2009).

The cysts referred in this study as A. tamarense type are morphologically identical to the cysts of $A$. tamarense but were not incubated to confirm their identity. Other species as A. catenella, Alexandrium acatenella and Alexandrium fundyense produce similar cysts hardly distinguishable from A. tamarense (Head et al., 2006 and literature therein) although A. catenella and $A$. fundyense are probably co-specific and molecular studies point in that direction that they form the $A$. tamarense species complex (Lilly et al., 2007). A. catenella, A. acatenella and A. tamarense are placed in the same clade using theca-based phylogeny and the nearly identical cyst morphologies reflect this close phylogenetic relationship (Matsuoka and Head, 2013).

\section{Results}

\subsection{Hydrography of the San Jorge Gulf (SJG)}

Further insight into the dynamical characteristics of the hydrographic fields can be obtained from the Simpson's stability parameter and Brunt-Väisälä frequency. The water column in the gulf region

\section{Table 2}

In situ measured chlorophyll-a (chl-a) concentrations, phaeopigment (phaeo) concentrations and chl-a:phaeo ratios in the different surface water masses along the Argentinean coast (SW = shelf water; SJG = San Jorge Gulf; BMW = Beagle-Magellan water; SAW $=$ Subantarctic water; $\mathrm{n}=$ number of samples). Values are average concentrations ( $\mu \mathrm{g}$ $\mathrm{L}^{-1}$ ) and standard deviations are given.

\begin{tabular}{lrlll}
\hline Water mass & \multicolumn{1}{c}{$\mathrm{n}$} & Chl-a $\left[\mu \mathrm{g} \mathrm{L}^{-1}\right]$ & Phaeo $\left[\mu \mathrm{g} \mathrm{L}^{-1}\right]$ & Ratio Chl-a:Phaeo \\
\hline SW & 7 & $1.74 \pm 0.6$ & $1.30 \pm 0.3$ & $1.37 \pm 0.3$ \\
SJG & 3 & $2.21 \pm 1.6$ & $0.79 \pm 0.1$ & $2.78 \pm 1.9$ \\
BMW-SAW & 25 & $0.45 \pm 0.2$ & $0.79 \pm 0.4$ & $0.70 \pm 0.3$ \\
\hline
\end{tabular}

Table 3

Most abundant and toxigenic planktonic species in mixed water samples from 3 and $10 \mathrm{~m}$ depth in the SJG region [1000 cells $\mathrm{L}^{-1}$ ].

\begin{tabular}{lcccccc}
\hline Station & \multicolumn{1}{c}{ S40 } & \multicolumn{1}{c}{ C43 } & C43N & I44 & C45 & P45B \\
\hline Total dinoflagellates & 5.28 & 33.85 & 25.56 & 5.70 & 9.06 & 3.56 \\
Ceratium tripos & 2.84 & 27.95 & 16.01 & 0.72 & 1.58 & 0.06 \\
Ceratium lineatum & - & 0.04 & 3.67 & 0.42 & 0.64 & 1.48 \\
Ceratium fusus & 0.12 & 0.36 & 2.65 & 0.12 & 0.72 & - \\
Total toxigenic dinoflagellates & 0.56 & 0.50 & 0.28 & 0.22 & 0.42 & 0.08 \\
Protoceratium reticulatum & - & 0.04 & 0.06 & 0.02 & 0.12 & - \\
Gonyaulax aff. spinifera & - & - & 0.12 & - & 0.14 & 0.02 \\
Dinophysis acuminata & & 0.06 & 0.10 & - & 0.16 & 0.06 \\
Alexandrium tamarense & 0.56 & 0.40 & - & 0.20 & - & - \\
Total diatoms & 26.80 & -0.44 & 0.12 & 1.64 & 0.26 & 6.14 \\
Pseudo-nitzschia australis & 5.24 & - & - & - & - & - \\
P. pungens & 0.20 & - & - & - & - & - \\
\hline
\end{tabular}

(Fig. 2) showed a strong stratification in the inner part of the gulf (values higher than $100 \mathrm{~J} \mathrm{~m}^{-3}$ ) and outside of the gulf at the easternmost station (transect I Fig. 2A, Fig. $2 \mathrm{~B} / \mathrm{C}$ ) (values higher than $60 \mathrm{~J} \mathrm{~m}^{-3}$ ). The water column appeared highly stratified and stable in the first $50 \mathrm{~m}$ of stations I44, C45 and C43 with values of Brunt-Väisälä frequency greater

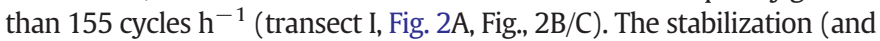
density structure) of the water column was mainly determined by temperature and salinity, with deeper water showing temperatures as low as $\sim 8{ }^{\circ} \mathrm{C}$ and the upper water layer reaching almost $14^{\circ} \mathrm{C}$. In contrast, at stations S40, C43N and P45B (transect II Fig. 2A, Fig. 2D/E) the Simpson parameter was only $0.4,4.7$ and $0.7 \mathrm{~J} \mathrm{~m}^{-3}$, respectively. The BruntVäisälä frequency was very low and the water column was mixed (transect II, Fig. 2A, Fig. 2D/E). The transition of water masses is further illustrated by a T-S diagram of selected stations (Fig. 4). On average, the Subantarctic Waters (SAW) were more saline, with salinities $>33.50$ and presented changes in the vertical temperature. The Beagle-Magellan Waters (BMW) were less dense than $25.50 \mathrm{~kg} \mathrm{~m}^{-3}$, with constant temperature $\left(\sim 8^{\circ} \mathrm{C}\right)$, and influenced by low-salinity coastal water (LSCW). The Argentinean Shelf Waters (SW) showed the highest temperatures and, at the northern stations were influenced by high-salinity coastal water (HSCW). The stations of the study area (Fig. 4, box) are illustrated in more detail. The stations of transect I showed variations in salinity and temperature in contrast to the stations of transect II.

\subsection{Nutrients}

Inorganic nutrients were largely depleted and DOC was slightly elevated at the surface (10 m water depth) of all stations in the SJG (Table 1), similar to all other stations north of the SJG at which SW was sampled. Only in the surface water of station P45B nitrate was elevated (11.4 $\mu \mathrm{M}$ nitrate). At water depths below $50 \mathrm{~m}$ inorganic nutrients were high ( $>14 \mu \mathrm{M}$ nitrate $>1.4 \mu \mathrm{M}$ phosphate). Station C43, east of the SJG, also showed higher nutrients in the deeper water $(88 \mathrm{~m}: 17.7 \mu \mathrm{M}$ nitrate and $1.5 \mu \mathrm{M}$ phosphate). Nitrate, phosphate and DOC concentrations in the

Table 4

Most abundant and toxigenic planktonic species in vertical net hauls in the SJG region [1000 cells NT ${ }^{-1}$ ].

\begin{tabular}{|c|c|c|c|c|c|c|}
\hline & S40 & $\mathrm{C} 43$ & $\mathrm{C} 43 \mathrm{~N}$ & I44 & $\mathrm{C} 45$ & P45B \\
\hline Total dinoflagellates & 4427 & 38,411 & 21,890 & 1547 & 20,015 & 4830 \\
\hline Ceratium tripos & 3480 & 35,800 & 15,640 & 464 & 2800 & 1092 \\
\hline Ceratium lineatum & 1 & 300 & 2880 & 415 & 12,800 & 1544 \\
\hline Ceratium fusus & 4 & 700 & 2040 & 118 & 2240 & 252 \\
\hline Toxigenic dinoflagellates & 80 & 235 & 130 & 64 & 284 & 88 \\
\hline Protoceratium reticulatum & - & 44 & 7 & 30 & 30 & 2 \\
\hline Gonyaulax aff. spinifera & - & 1 & 76 & 13 & 82 & 6 \\
\hline Dinophysis acuminata & - & 42 & 47 & 4 & 168 & 80 \\
\hline Alexandrium tamarense & 80 & 148 & - & 17 & 4 & - \\
\hline Total diatoms & 21,583 & 239 & 110 & 20 & 47 & 231 \\
\hline Pseudo-nitzschia australis & 4320 & 16 & - & - & 4 & - \\
\hline P. pungens & 4200 & - & - & - & - & - \\
\hline
\end{tabular}


Table 5

Abundances of heterotrophic bacteria (HB) and autotrophic picoplankton (AP) in the different surface water masses along the Argentinean coast $(\mathrm{SW}=$ shelf water; SJG $=$ San Jorge Gulf; BMW = Beagle-Magellan water; SAW = Subantarctic water; $\mathrm{n}=$ number of stations). Values (cell $\mathrm{mL}^{-1}$ ) are average and standard deviations are given.

\begin{tabular}{lrll}
\hline Water mass & $\mathrm{n}$ & $\mathrm{HB}\left[10^{6}\right.$ cells $\left.\mathrm{mL}^{-1}\right]$ & $\mathrm{AP}\left[10^{4}\right.$ cells $\left.\mathrm{mL}^{-1}\right]$ \\
\hline SW & 7 & $1.18 \pm 0.46$ & $2.64 \pm 1.71$ \\
SJG & 3 & $0.61 \pm 0.11$ & $0.66 \pm 0.42$ \\
BMW-SAW & 24 & $1.06 \pm 0.37$ & $0.97 \pm 0.66$ \\
\hline
\end{tabular}

BMW were moderately high. Compared to the SJG and SW, inorganic nutrients in the SAW samples south of the SJG were higher and DOC was lower.

\subsection{Phycopigments and satellite images}

Mean chl-a values derived from satellite images of the SJG for the week between 6th and 13th April 2012 were highest (up to $5 \mathrm{mg} \mathrm{m}^{-3} \mathrm{chl}-\mathrm{a}$ ) to the east of SJG mouth (Fig. 3A), where the water column was stratified (Fig. 2B/C). In general chl-a values were lower in the SJG area during the two weeks before and after 6th to 13th April 2012 (data not shown).

Relative low chl-a concentrations were detected in the inner SJG (Fig. 3A). Chl-a concentrations measured in situ (Table 2) were generally in the same range with the data derived from satellite images. Ratios of chl-a to phaeopigments throughout the entire expedition transect ranged between 0.08 and 4.92 and were highest in the SJG (Table 2).

\subsection{Phytoplankton composition in the SJG}

\subsubsection{Nano- and microplankton}

Abundance of phytoplankton ( $>2 \mu \mathrm{m}$ ), estimated by microscopic analysis following the Utermöhl method, showed similar values in the SJG and adjacent waters, ranging between $9.0 \times 10^{3}$ and $36.4 \times 10^{3}$ cells $\mathrm{L}^{-1}$ (Fig. 3B). However, assemblages dominated by dinoflagellates and diatoms were respectively observed inside and outside the SJG (Fig. 3B). A bloom of Ceratium spp. (mainly Ceratium tripos but also Ceratium lineatum and Ceratium fusus), representing up to $85 \%$ of total phytoplankton abundance, was found towards offshore stations of the SJG (C43 and C43N). Small gymnodinioid dinoflagellates $(<20 \mu \mathrm{m})$ exceeded Ceratium abundances at the inner stations of the SJG. In contrast, samples collected both north and south of the SJG were dominated by diatoms, which represented 58\% (station P45B) and $80 \%$ (station S40) of total abundance. Station P45B, with a total diatom abundance of $6.1 \times 10^{3}$ cells $\mathrm{L}^{-1}$, was dominated by centric diatoms including a small Thalassiosira (10-30 $\mu \mathrm{m})$ and Paralia sulcata.
On the other hand, station S40 showed the highest diatom abundance $\left(27 \times 10^{3}\right.$ cells $\left.\mathrm{L}^{-1}\right)$. It was dominated by centric taxa, mainly Rhizosolenia pungens, Paralia sulcata and Thalassiosira sp. (40-50 $\mu \mathrm{m})$, but pennate diatoms of the genus Pseudo-nitzschia were also abundant (Tables 3 and 4).

\subsubsection{Heterotrophic bacteria and autotrophic picoplankton}

Highest numbers of heterotrophic (HB) (average of $1.18 \times$ $10^{6}$ cells $\mathrm{mL}^{-1}$ ) and autotrophic picoplankton (AP) (average of $2.64 \times 10^{4}$ cells $\mathrm{mL}^{-1}$ ) were found at stations to the north of SJG. Lower levels of bacteria were detected in the SJG (Table 5). Our data (Fig. 5) suggest a latitudinal trend with decreasing HB abundances from the north to the northern edge of the SJG $\left(42^{\circ} \mathrm{S}\right.$ to $\left.45^{\circ} \mathrm{S}\right)$ and increasing abundances from the southern edge of the SJG to the south and a subsequent decrease $\left(47.5^{\circ} \mathrm{S}\right.$ to $\left.55.5^{\circ} \mathrm{S}\right)$. The AP abundances seem to follow the same trend, and this seems to depend on a physical variable such as temperature (see data subgroup in Fig. 5 and below). However, the ratios between AP and HB are lower in SW in the north than in BMW in the south.

In the SJG and SW regions $\mathrm{HB}$ and AP showed a positive correlation (Table 6) with surface seawater temperature (SST), and HB also with surface seawater salinity (SSS). No significant correlations were found between HB and chl-a, phaeo. However, AP showed a positive correlation only with phaeo (Table 6). An exception was the station I47, (Valdés Front), this area is characterized by highest productivity (Acha et al., 2004) and densities of bacterioplankton on the Argentine shelf (Alder and Franzosi, 2004) (Fig. 5, dashed circle). South of the SJG, in the Beagle-Magellan and Subantarctic waters (BMW-SAW) HB and AP showed a positive correlation with SST. They also showed a strong negative correlation with SSS. Significant correlations were found for picoplanktonic abundance and chl-a and phaeo (Table 6).

\subsubsection{Description of the isolate of A. tamarense}

Based on thecal plate pattern determined under the fluorescence microscope (exemplarily shown for isolate H7 in Fig. 6), both isolates were identified as A. tamarense. During exponential growth in culture, cells mainly occurred as single units or in short two-cell chains. Cells with the typical horseshoe-shaped central nucleus were nearly spherical (Fig. 6A), with length and width of about $35 \mu \mathrm{m}$. The first apical plate consistently had a small ventral pore (Fig. 6D).

The PSP toxin profiles of strains $\mathrm{H} 5$ and $\mathrm{H} 7$ are almost identical consisting of $57 \% \mathrm{GTX} 1 / 4,40 \% \mathrm{C} 1 / 2$ and minor proportions of NEO, GTX2/3, B1 and STX (Fig. 7). Total PSP toxin content of strains H5 and H7 was $74 \mathrm{pg}$ cell $^{-1}$ and $60 \mathrm{pg}$ cell $^{-1}$, respectively.

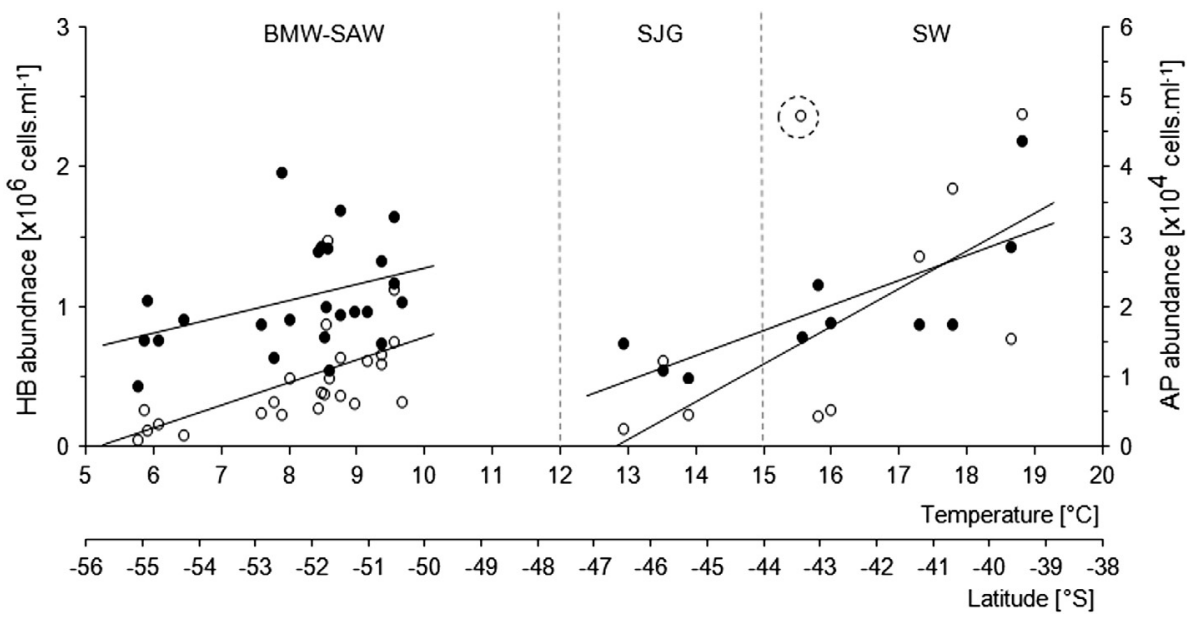

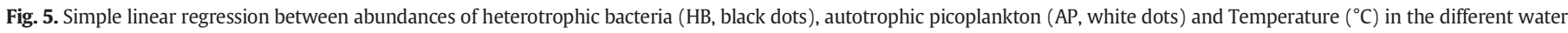

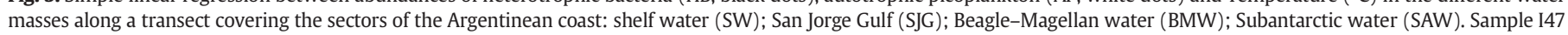
(encircling dashed line). 
Table 6

The Pearson's product-moment correlation coefficient. The p value is based on significance test for the correlation coefficient. SST, surface seawater temperature; SSS, surface seawater salinity; Chl-a, cholorophyll a; HB, heterotrophic bacteria; AP, autotrophic picoplankton; SGJ, San Jorge Gulf; SW, shelf water; BMW, Beagle-Magellan water; SAW, Subantartic water.

\begin{tabular}{lllcc}
\hline Variable & $\mathrm{H} B_{\mathrm{SJG}-\mathrm{SW}}$ & $\mathrm{AP}_{\mathrm{SJG}-\mathrm{SW}}$ & $\mathrm{HB}_{\mathrm{BMW}-\mathrm{SAW}}$ & $\mathrm{AP}_{\mathrm{BMW}-\mathrm{SAW}}$ \\
\hline SST & $0.812^{* *}$ & $0.67^{*}$ & $0.43^{*}$ & $0.78^{* *}$ \\
SSS & $0.80^{* *}$ & $\mathrm{~ns}$ & $-0.55^{* *}$ & $-0.46^{*}$ \\
Chl-a & $\mathrm{ns}$ & $\mathrm{ns}$ & $0.49^{*}$ & $0.56^{* *}$ \\
\hline
\end{tabular}

${ }^{*} \mathrm{p}<0.05 ;{ }^{* *} \mathrm{p}<0.01 ;$ ns, not significant.

\subsubsection{Dinocysts in surface sediments}

Photosynthetic taxa in the surface sediments were represented by cysts of Gonyaulax aff. spinifera, Protoceratium reticulatum and $A$. tamarense type (Fig. 8A). Heterotrophic assemblages included cysts of diverse species of Protoperidinium, Archaeperidinium minutum, Diplopsalidaceae, and the Polykrikos kofoidii/Polykrikos schwartzii complex. These cysts were grouped as heterotrophic cysts for the purpose of this work (Table 7 ). The total dinocyst abundance ranged from $0.64 \times 10^{3}$ to $2.1 \times 10^{3}$ cysts $\mathrm{g}^{-1}$ sediment wet weight (with a mean

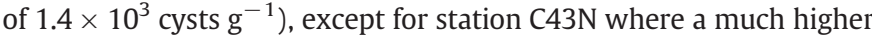
value $\left(17.1 \times 10^{3}\right.$ cysts $\left.\mathrm{g}^{-1}\right)$ was reached (Fig. $\left.8 \mathrm{~B}\right)$. The bottom sediment texture is heterogeneous (Fig. 8B) consisting of sabulitic (coarse) sandy silt, sandy silt and clayey silt, suggesting different hydrodynamic conditions with a probable control over the distribution of dinocysts, similar in size to fine silt particles of the sediment.

\subsubsection{Occurrence of toxic phytoplankton species}

Six potentially toxic phytoplankton species were found in the SJG, four of them dinoflagellates (A. tamarense, Dinophysis acuminata, Gonyaulax aff. spinifera and P. reticulatum) and the other two diatoms (Pseudo-nitzschia australis and Pseudo-nitzschia pungens). A. tamarense,

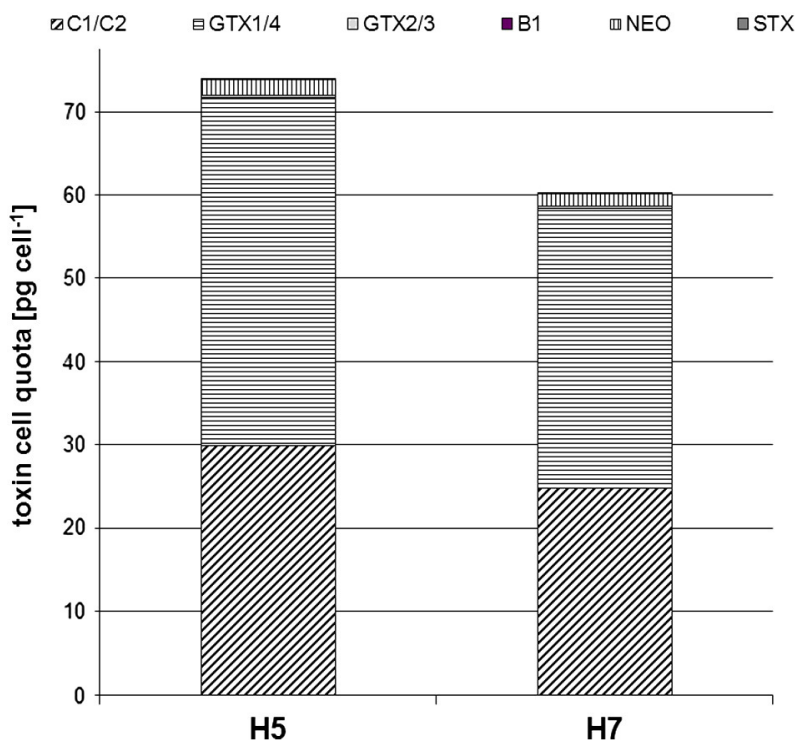

Fig. 7. PSP toxin profiles and toxin cell quotas of $A$. tamarense strains $\mathrm{H} 5$ and $\mathrm{H} 7$ isolated from station $\mathrm{C} 43$

the putative source of PSP, was present in all net samples examined except in P45B located north of the SJG and C43N, where the lowest concentration of PSP toxins was detected. Moreover, the highest abundance of $148 \times 10^{3}$ cells $\mathrm{NT}^{-1}$ coincided with the maximum PSP concentration (Table 4, Fig. 9A). Gonyaulax aff. spinifera and P. reticulatum, two potential producers of YTX, were present in the SJG stations and also northward, and coincided with the occurrence of yessotoxins (Fig. 9B/C). However, no clear correspondence was found between cell
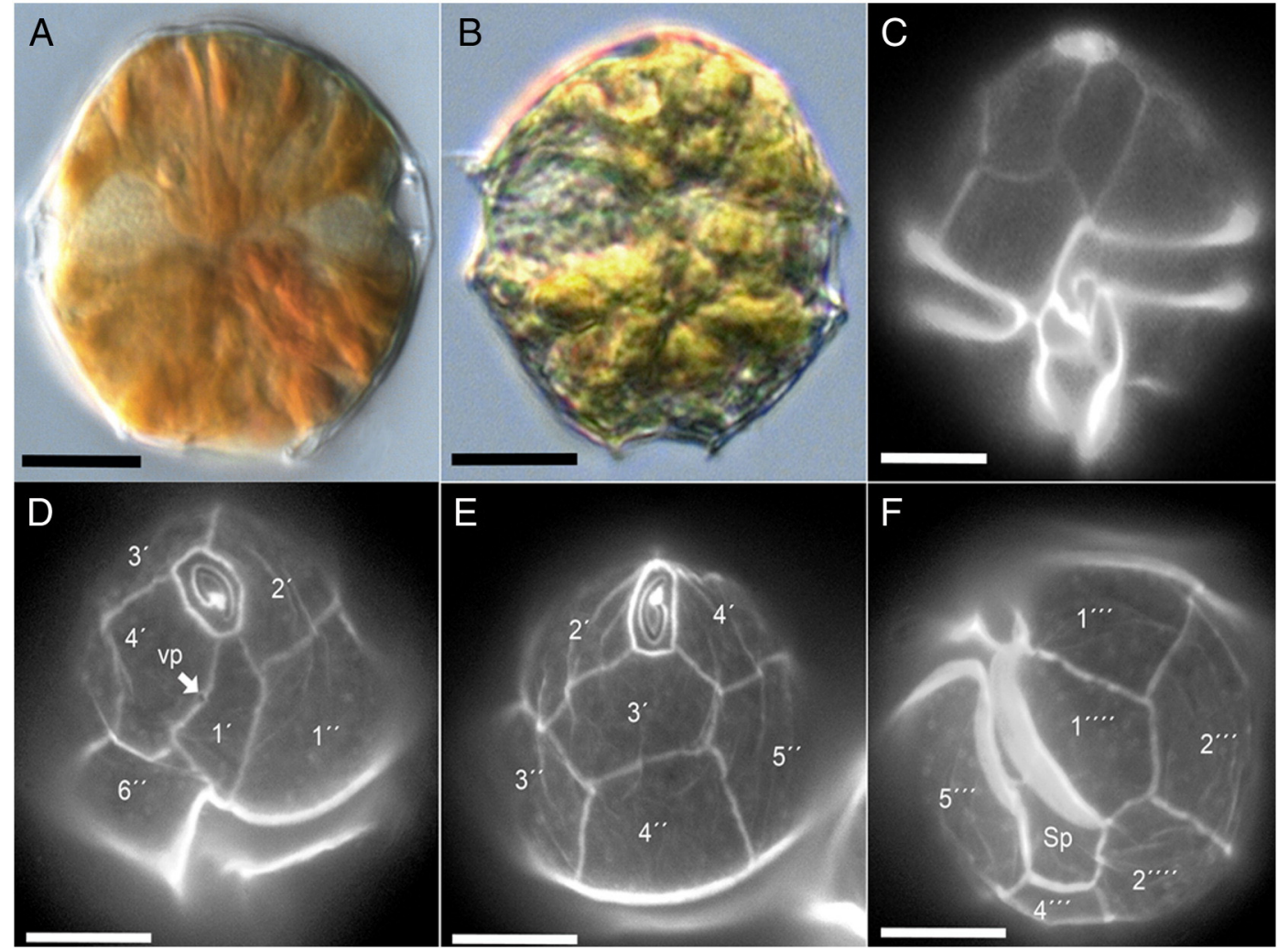

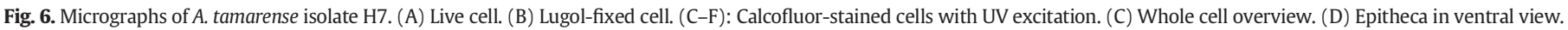
Note the small ventral pore (vp, arrow). (E) Epitheca in dorsal view. (F) Hypothecal plates. Note that the dorsal postcingular plate $3^{\prime \prime \prime}$ is not visible. Scale bar $=10$ um. 

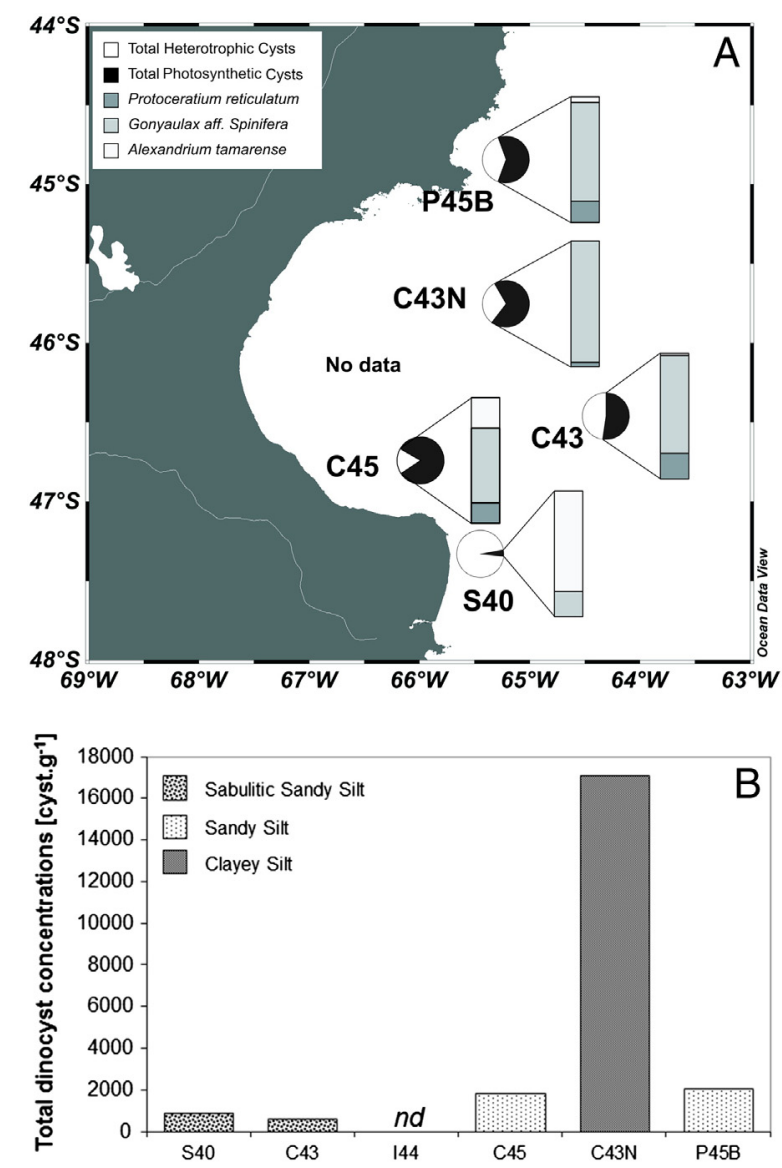

Fig. 8. A. Abundances of the most frequent dinoflagellate cysts present in the samples and relative abundances of cysts of photosynthetic species and cysts of heterotrophic species; $8 \mathrm{~B}$ : Total cyst concentrations in the SJG region (nd = no data).

density and toxin concentration for any of the two species. A similar case was found for D. acuminata, the putative source of PTX-2. While a general coincidence in the presence of $D$. acuminata and PTX-2 was observed, no clear relation was found between cell density and toxin concentration. The diatom genus Pseudo-nitzschia was found in low densities in the two southernmost stations of the SJG. In contrast, a maximum of about $8.5 \times 10^{6}$ cells $\mathrm{NT}^{-1}$ was recorded southwards (S40) together with the highest concentration of DA in the 50-200 $\mu \mathrm{m}$ fraction. This maximum was represented by $P$. australis and $P$. pungens, which are known as potential DA producer species. However, the distribution of these species did not always coincide with toxin detection. For example, in some stations (C43N, I44) no Pseudo-nitzschia was observed even though DA was detected, while the occurrence of $P$. australis at C43 did not coincide with the presence of DA.

\subsection{Phycotoxins}

Four toxin groups were detected in phytoplankton samples along the entire cruise transect from Ushuaia to Mar del Plata: domoic acid (DA) causing the amnesic shellfish poisoning (ASP) syndrome was only detected in the Eastern Beagle Channel and in the mouth of the Beagle Channel (stations I2 and I3) and in the SJG region with a maximum value of $295 \mathrm{ng} \mathrm{NT}^{-1}$ at station C45. Yessotoxin (YTX), a lipophilic algal toxin usually co-extracted with diarrhetic shellfish poisoning (DSP) toxins, was exclusively found in the SJG region (24-343 ng NT ${ }^{-1}$ ), whereas pectenotoxins (PTXs), also regarded as a toxin group of the DSP complex, were occasionally found in varying abundances (4$680 \mathrm{ng} \mathrm{NT}^{-1}$ ) along the entire expedition transect from latitude $56^{\circ} \mathrm{S}$ (south of Tierra del Fuego) up to latitude $38^{\circ} \mathrm{S}$ (Mar del Plata). Paralytic shellfish poisoning (PSP) toxins represented the most abundant toxin group with up to $5.3 \mu \mathrm{gTT}^{-1}$ in the SJG region (Fig. 9A, Table 8). Yet, lower levels were also found south of Tierra del Fuego $\left(56^{\circ} \mathrm{S}\right)$ and in the Bahía Grande area $\left(51-52^{\circ} \mathrm{S}\right)$. PSP toxin profiles consisted only of the equilibrium ratio of GTX2/3 and traces of STX. Azaspiracids, cyclic imine toxins like spirolides and gymnodimines, pinnatoxins, okadaic acid and dinophysistoxins were not detected along the entire transect. Most toxins were found in the $20-50 \mu \mathrm{m}$ size fractions, where most toxigenic plankton species are found. Only in the SJG region the 50-200 $\mu \mathrm{m}$ fractions contained DA and PTX-2 up to approximately $500 \mathrm{ng} \mathrm{NT}^{-1}$ and in lower concentration YTX. In addition, 2400 and $230 \mathrm{ng} \mathrm{NT}^{-1}$ PTX-2sa were measured at stations 150 and I52, respectively, but no PSP toxins were found in the 50-200 $\mu \mathrm{m}$ size fractions. In the $>200 \mu \mathrm{m}$ fraction only sporadic and low (max. $100 \mathrm{ng} \mathrm{NT}{ }^{-1}$ ) levels of PTX-2sa were detected at few stations.

\section{Discussion}

\subsection{Water masses of the Argentinean shelf}

The oceanographic data collected during the expedition (data not shown) were consistent with previous descriptions of Argentinean coastal water masses. The main source of water masses in the Argentinean Shelf is the Malvinas/Falkland Current (MC) that originates from Subantarctic Waters (SAW). SAW is derived from the north of the Drake Passage, flows as Cape Horn Current (Guerrero and Piola, 1997; Piola et al., 2010) and turns northward as the MC between the eastern edge of the Argentinean shelf with the Islas Malvinas and the Argentinean coast (Bianchi et al., 1982). Significant contributions of low-salinity waters enter the MC from continental run offs and melt water through the Strait of Magellan and the Beagle Channel (BMW), which is indicated by lowest salinities in the region at the eastern mouths of the Beagle Channel and the Strait of Magellan (Fig. 1B). The BMW causes the formation of a coastal low-salinity tongue (LSCW) ( $<33.4$, see Fig. 1B), which can be detected up to about $45^{\circ} \mathrm{S}$, and then continues with shelf water or midshelf water (SW), ranging from 33.4 to 33.8 , along the central shelf up to $40^{\circ} \mathrm{S}$ (Bianchi et al., 2005). High-salinity coastal waters (HSCW) close to north of $42^{\circ} \mathrm{S}$ and continue to the north to collide with Rio de la Plata estuary.

4.1.1. Oceanographic parameters and biogeographical association of plankton toxins with particular water masses

The general water mass characteristics in the San Jorge Gulf were particularly driven by four factors: (i) the Argentinean Shelf Water (SW), (ii) the Beagle-Magellan Water (BMW), (iii) the Malvinas Current (MC) and (iv) the topographical depressions in the inner part of the gulf (Matano et al., 2010).

Table 7

Cyst concentration in surface sediment samples [1000 cysts $\left.\mathrm{g}^{-1}\right]$ (nd $=$ not detected).

\begin{tabular}{|c|c|c|c|c|c|c|}
\hline Sta. & Total autotrophic cysts & Total heterotrophic cysts & Protoceratium reticulatum & Gonyaulax aff. spinifera & Alexandrium tamarense type & Total cyst \\
\hline S40 & 0.04 & 0.85 & 0 & 0.008 & 0.032 & 0.89 \\
\hline C43 & 0.33 & 0.30 & 0.07 & 0.25 & 0.006 & 0.64 \\
\hline $\mathrm{C} 43 \mathrm{~N}$ & 11.75 & 5.34 & 0.40 & 11.35 & 0 & 17.09 \\
\hline 144 & nd & nd & nd & nd & nd & nd \\
\hline $\mathrm{C} 45$ & 1.52 & 0.33 & 0.25 & 0.90 & 0.37 & 1.85 \\
\hline P45B & 1.28 & 0.81 & 0.22 & 1.00 & 0.06 & 2.09 \\
\hline
\end{tabular}




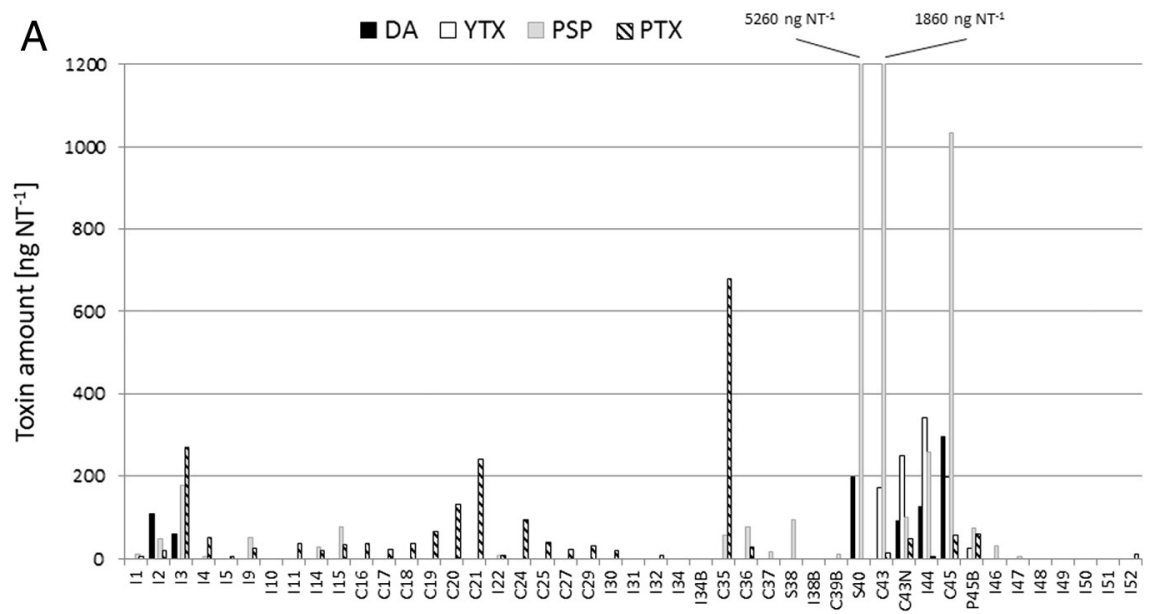

B

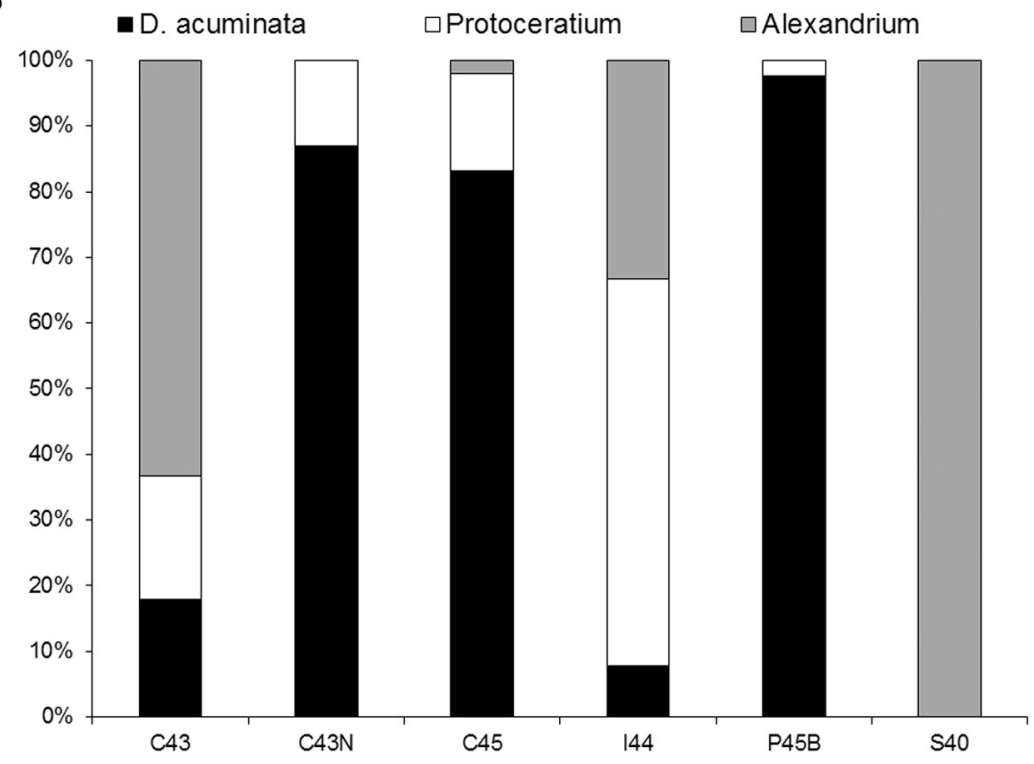

C

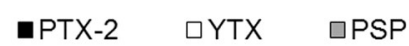

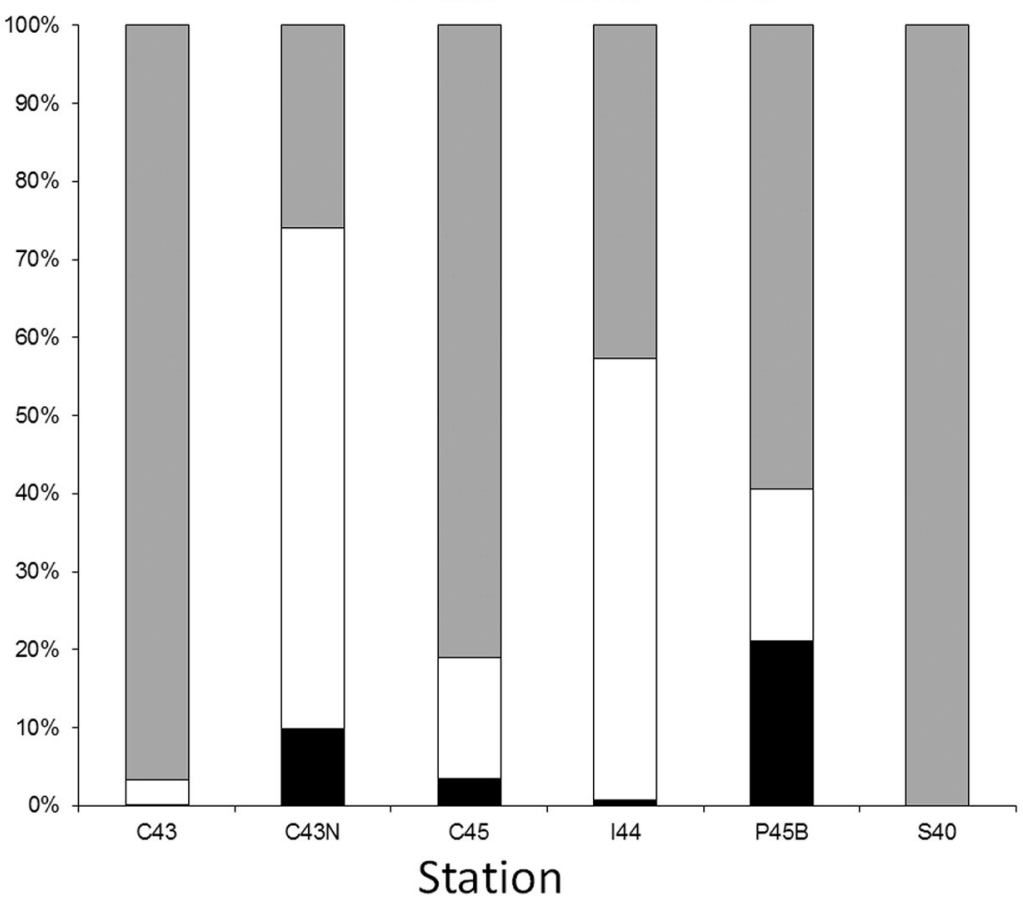


Table 8

Phycotoxin amounts in $20 \mathrm{~m}$ vertical net haul size fractions along the entire expedition transect $(0=$ below limit of detection).

\begin{tabular}{|c|c|c|c|c|c|c|c|c|c|c|c|c|}
\hline \multirow[b]{4}{*}{ Station } & \multicolumn{6}{|c|}{$20-50 \mu \mathrm{m}$} & \multicolumn{5}{|c|}{$50-200 \mu \mathrm{m}$} & \multirow{4}{*}{$\begin{array}{l}\frac{>200 \mu \mathrm{m}}{\text { Toxin amount }} \\
\frac{\text { ng NT }^{-1} \text { ] }}{\text { PTX-2sa }}\end{array}$} \\
\hline & \multicolumn{6}{|c|}{ Toxin amount } & \multicolumn{5}{|c|}{ Toxin amount } & \\
\hline & \multicolumn{6}{|c|}{$\left[\mathrm{ng} \mathrm{NT}^{-1}\right]$} & \multicolumn{5}{|c|}{$\left[\mathrm{ng} \mathrm{NT}^{-1}\right]$} & \\
\hline & $\mathrm{DA}$ & PTX-2 & PTX-2sa & sum PTX & YTX & PSP & DA & PTX-2 & PTX-2sa & sum PTX & YTX & \\
\hline I1 & 0 & 4 & 0 & 4 & 0 & 10 & 0 & 0 & 0 & 0 & 0 & 0 \\
\hline $\mathrm{I} 2$ & 110 & 20 & 0 & 20 & 0 & 47 & 0 & 0 & 0 & 0 & 0 & 0 \\
\hline I3 & 60 & 192 & 78 & 270 & 0 & 179 & 0 & 0 & 0 & 0 & 0 & 0 \\
\hline 14 & 0 & 36 & 15 & 51 & 0 & 5 & 0 & 0 & 0 & 0 & 0 & 0 \\
\hline I5 & 0 & 6 & 0 & 6 & 0 & 0 & 0 & 0 & 0 & 0 & 0 & 0 \\
\hline I9 & 0 & 22 & 2 & 25 & 0 & 51 & 0 & 0 & 0 & 0 & 0 & 0 \\
\hline $\mathrm{I} 14$ & 0 & 0 & 0 & 0 & 0 & 0 & 0 & 0 & 0 & 0 & 0 & 0 \\
\hline $\mathrm{I} 10$ & 0 & 24 & 12 & 36 & 0 & 0 & 0 & 0 & 0 & 0 & 0 & 0 \\
\hline I11 & 0 & 8 & 10 & 18 & 0 & 28 & 0 & 0 & 0 & 0 & 0 & 0 \\
\hline I15 & 0 & 32 & 3 & 35 & 0 & 78 & 0 & 0 & 0 & 0 & 0 & 0 \\
\hline C18 & 0 & 38 & 0 & 38 & 0 & 0 & 0 & 0 & 0 & 0 & 0 & 0 \\
\hline C17 & 0 & 23 & 0 & 23 & 0 & 0 & 0 & 0 & 0 & 0 & 0 & 0 \\
\hline C16 & 0 & 37 & 0 & 37 & 0 & 0 & 0 & 0 & 0 & 0 & 0 & 0 \\
\hline $\mathrm{C} 25$ & 0 & 60 & 5 & 65 & 0 & 0 & 0 & 0 & 0 & 0 & 0 & 0 \\
\hline I22 & 0 & 124 & 7 & 131 & 0 & 0 & 0 & 0 & 0 & 0 & 0 & 0 \\
\hline C19 & 0 & 220 & 22 & 242 & 0 & 0 & 0 & 0 & 0 & 0 & 0 & 0 \\
\hline $\mathrm{C} 20$ & 0 & 8 & 0 & 8 & 0 & 7 & 0 & 0 & 0 & 0 & 0 & 44 \\
\hline $\mathrm{C} 21$ & 0 & 93 & 2 & 95 & 0 & 0 & 0 & 0 & 0 & 0 & 0 & 0 \\
\hline $\mathrm{C} 24$ & 0 & 34 & 6 & 39 & 0 & 0 & 0 & 0 & 0 & 0 & 0 & 0 \\
\hline $\mathrm{C} 27$ & 0 & 23 & 0 & 23 & 0 & 0 & 0 & 0 & 0 & 0 & 0 & 0 \\
\hline I31 & 0 & 32 & 0 & 32 & 0 & 0 & 0 & 0 & 0 & 0 & 0 & 0 \\
\hline $\mathrm{I} 30$ & 0 & 19 & 0 & 19 & 0 & 0 & 0 & 0 & 0 & 0 & 0 & 0 \\
\hline $\mathrm{C} 29$ & 0 & 0 & 0 & 0 & 0 & 0 & 0 & 0 & 0 & 0 & 0 & 0 \\
\hline C35 & 0 & 8 & 0 & 8 & 0 & 0 & 0 & 0 & 0 & 0 & 0 & 0 \\
\hline C36 & 0 & 0 & 0 & 0 & 0 & 0 & 0 & 0 & 0 & 0 & 0 & 0 \\
\hline C37 & 0 & 0 & 0 & 0 & 0 & 0 & 0 & 0 & 0 & 0 & 0 & 0 \\
\hline I34 & 0 & 624 & 56 & 680 & 0 & 55 & 0 & 0 & 0 & 0 & 0 & 0 \\
\hline I32 & 0 & 30 & 0 & 30 & 0 & 78 & 0 & 0 & 0 & 0 & 0 & 0 \\
\hline I34B & 0 & 3 & 0 & 3 & 0 & 17 & 0 & 0 & 0 & 0 & 0 & 0 \\
\hline S38 & 0 & 0 & 0 & 0 & 0 & 95 & 0 & 0 & 0 & 0 & 0 & 0 \\
\hline I38B & 0 & 0 & 0 & 0 & 0 & 0 & 0 & 0 & 0 & 0 & 0 & 0 \\
\hline С $39 \mathrm{~B}$ & 0 & 0 & 0 & 0 & 0 & 10 & 0 & 0 & 0 & 0 & 0 & 0 \\
\hline S40 & 198 & 0 & 0 & 0 & 0 & 1807 & 562 & 0 & 0 & 0 & 0 & no data \\
\hline C43 & 0 & 9 & 5 & 14 & 173 & 5257 & 0 & 578 & 266 & 844 & 160 & 75 \\
\hline $\mathrm{C} 43 \mathrm{~N}$ & 91 & 38 & 11 & 49 & 248 & 100 & 0 & 0 & 0 & 0 & 68 & 0 \\
\hline $\mathrm{I} 44$ & 127 & 4 & 0 & 4 & 343 & 259 & 0 & 277 & 147 & 423 & 0 & 0 \\
\hline C45 & 295 & 45 & 11 & 56 & 197 & 1035 & 0 & 420 & 215 & 635 & 75 & 28 \\
\hline P45B & 0 & 27 & 34 & 60 & 24 & 75 & 0 & 0 & 104 & 104 & 0 & 0 \\
\hline $\mathrm{I} 46$ & 0 & 0 & 0 & 0 & 0 & 31 & 0 & 0 & 0 & 0 & 0 & 0 \\
\hline I47 & 0 & 0 & 0 & 0 & 0 & 5 & 0 & 0 & 0 & 0 & 0 & 0 \\
\hline $\mathrm{I} 48$ & 0 & 0 & 0 & 0 & 0 & 0 & 0 & 0 & 0 & 0 & 0 & 0 \\
\hline I49 & 0 & 0 & 0 & 0 & 0 & 0 & 0 & 0 & 0 & 0 & 0 & 0 \\
\hline $\mathrm{I} 50$ & 0 & 0 & 0 & 0 & 0 & 0 & 0 & 106 & 2396 & 2502 & 0 & 107 \\
\hline I51 & 0 & 0 & 0 & 0 & 0 & 0 & 0 & 0 & 0 & 0 & 0 & 0 \\
\hline I52 & 0 & 0 & 11 & 11 & 0 & 0 & 0 & 0 & 234 & 234 & 0 & 41 \\
\hline
\end{tabular}

The SJG water mainly originates from SW modified by the contributions of coastal waters, whose salinity spatially and temporally varies between 33.0 and 33.6 (Fernández et al., 2007). Coastal waters flow northward from the Strait of Magellan along the coast (Fig. 1B) and consist of a mixture of SAW and low-salinity BMW waters derived from continental input (Brandhorst and Castello, 1971) (Fig. 4). In the SJG region, it splits into two branches: one branch enters to the gulf in the southeast and influences the entire region throughout the year. The other branch flows away from the coast towards N-NE, thus separating the water masses inside the SJG from those, east of the gulf. Between these two stratified water bodies lies a zone of well mixed waters above a ridge in the mouth of the SJG (Fig. 2) driven by winds. Our CTD profile data agree well with previous findings on tides (Piola and Rivas, 1997) and the general oceanography of the SJG (Baldoni, 1990). Tidal fronts generate seasonal development and retention during the spring and late autumn (Carreto et al., 1985, 1986; Glorioso and Flather, 1997; Guerrero and Piola, 1997).

At the surface of all stations inside and near the gulf, the water was derived from the warm and saline Brazil Current referred as SW (Brandini et al., 2000). In the deeper layers of the stratified stations the water was derived from cold and less saline BMW (Piola and Rivas, 1997). The influence of the Patagonian Current was verifiable at intermediate depths $(45 \mathrm{~m}$ ) and characterized by a particularly low salinity. The occurrence of this water mass in the SJG was previously described in Gómez et al. (2011) and our results confirm this.

Even though the water in the deep basin of the SJG (station I44) was derived from nutrient enriched BMW, total inorganic nitrogen (TIN) and phosphate in the basin was higher compared to BMW. As the nutrient input from rivers in the arid climate around the gulf is low, higher nutrients in the bottom water can only be explained by remineralization

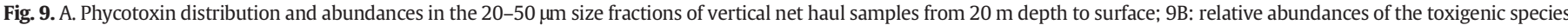

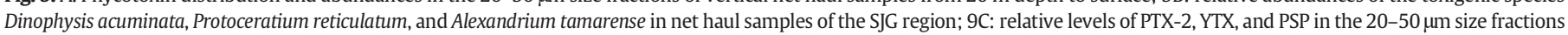
in net haul samples of the SJG region. 
of organic matter. These additional nutrients may also be explained by sedimentation of decaying plankton blooms, which frequently occur in the SJG. In addition, high nutrient conditions can also only build up if water residence times in the deep basin are relatively long compared to the overlying shelf water. This interpretation is supported by the formation of quasi stationary (counterclockwise) gyre and boundary currents in SJG generated by the wind-driven circulation as is predicted by the numerical model of circulation of Palma et al. (2004).

The BMW entering the SJG generates an intense thermohaline front from its southern end, which would stay at variable positions in the SJG during southern winter, spring, and summer, but moves to the north in autumn as has been proposed by several authors (Akselman, 1996; Guerrero and Piola, 1997).

These conditions of the water column define environmental conditions that favor dinoflagellate blooms (Gargett, 1997; Smayda, 1997). At the stations within the SJG, where BMW was superimposed by SW, the dinoflagellate proportion was always $>80 \%$ and dinoflagellates dominated diatoms. At the adjacent stations in the north and the south of the SJG, which were not stratified and influenced only by one water mass, the dinoflagellate:diatom ratio was almost reversed with diatoms contributing up to 60 and $80 \%$ of the total plankton community at station P45B and S40, respectively (Fig. 3B).

It has to be taken into account that the determination of plankton communities is highly dependent on the applied methods. Plankton cell counts of a defined volume of sea water are regarded to be quantitative values, even though they represent the sampled depth and are not necessarily representative for the whole water column. In contrast, vertical net hauls can be regarded as more representative of the water column at a certain sampling point. However, plankton smaller than the mesh size of the net (here: $20 \mu \mathrm{m}$ ) are not retained and plankton net hauls are not quantitative in a strict sense, because it is difficult to precisely estimate the volume sampled by the net. For these reasons, ratios of net haul and sea water plankton counts can be quite different (Tables 3 and 4).

It has been reported before that stratified water masses favor photosynthetic dinoflagellates, which, in contrast to diatoms, due to their flagella show active swimming behavior and perform diurnal migrations in order to take up nutrients in deeper parts of the water column during night and to photosynthesize close to surface during day-time (Cullen and Horrigan, 1981; Eppley et al., 1968; Ji and Franks, 2007; Smayda, 1997). Such a preference of dinoflagellates for stratified water was also reflected by the distribution of phycotoxins. The only phycotoxin sporadically detected throughout the entire expedition transect (Fig. 9A) was pectenotoxin-2 (PTX-2), produced by several species of the genus Dinophysis. However, Dinophysis, even though they contain chloroplasts, are obligate predators and for sustained growth need the ciliate Mesodinium rubrum as prey (Park et al., 2006). This dependence on specific prey may be an explanation for the distribution of Dinophysis spp. that largely differs from most other photosynthetic dinoflagellates. All other dinoflagellate toxin groups in Argentinean coastal waters, such as paralytic shellish poisoning (PSP) toxins and yessotoxin (YTX), were only detected in the SJG (with the exception of the Beagle Channel and its eastern mouth). Thus they strongly related with the occurrence of stratified water masses, not only in the inner gulf such as at station I44, but in much higher abundance at large distance from the coast (station C43).

Chlorophyll values were relatively low and consistent with those reported for middle and outer shelf waters during early autumn on the Argentine Shelf (Bianchi et al., 2005; Rivas et al., 2006; Lara et al., 2010).

In addition, it is noteworthy that the high dinoflagellate concentrations were only observed in the outer SJG, but not in the inner gulf, even though the hydrographic conditions of both areas are similar. This is especially interesting, because the major cyst beds are not located in any of the two regions, but on the ridge at the mouth of the SJG (Fig. 2B/C), which separates the inner and outer SJG.

\subsection{Abundances of heterotrophic bacteria and autotrophic picoplankton}

A difference between the HB and AP abundance was observed that seemed to depend on the physicochemical conditions of the water masses in the south (BMW) and north (SW) of the SJG (Figs. 1B, $2 \mathrm{~B} / \mathrm{C}$ ). The SJG proved to be a transition zone between these large water masses.

The positive covariation found to the south of $47^{\circ} \mathrm{S}$ for picoplanktonic abundance and chl-a (Table 2), showed the importance of picoplankton for the contribution to primary productivity in this zone. However, this scenario is not the same for the Argentinean shelf north of $47^{\circ} \mathrm{S}$, where no correlations between AP and chl-a were found.

Our results show the coincidence of decreasing bacterial and increasing dinoflagellate abundances, and this seems to be characteristic during blooms dominated by dinoflagellates in the SJG. It has been shown that bacteria generate favorable environments for the development of phytoplankton, especially dinoflagellates and the formation or ecdysis of their cysts (Mayali et al., 2007).

\subsection{Dinocyst composition}

The dinocyst composition of surface sediments showed a dominance of photosynthetic taxa in the SJG except for station S40, where a high number of cysts of heterotrophic species occurred. High abundance of heterotrophic species might indicate high abundance of prey organisms, and many of the Protoperidinium species have been shown to preferentially feed on large diatoms (e.g. Sherr and Sherr, 2007; Taylor and Pollingher, 1987). The analyses of the phytoplankton community in the water column are consistent with this observation showing an important increase in the number of diatom cells $\left(26.8 \times 10^{3}\right.$ cells $\mathrm{L}^{-1}$ at station S40, Table 3), sustained here by the nutrient-rich surface BMW. The abundance of Gonyaulax aff. spinifera cysts predominated followed by cysts of $P$. reticulatum. The only exception was observed at station C45 where cysts of the A. tamarense type reached the highest values exceeding those of $P$. reticulatum. Cysts of $A$. tamarense were also registered at C43 east of the SJG, at S40 south of the SJG and at P45B north of the SJG. This was in agreement with the detection of the related motile cells in the phytoplankton community.

The elevated cyst concentration of the photosynthetic group $\left(11.75 \times 10^{3}\right.$ cysts $\left.^{-1}\right)$ at station $C 43 \mathrm{~N}$, represented almost exclusively by a high value of $G$. aff. spinifera cysts $\left(11.35 \times 10^{3}\right.$ cysts $\left.\mathrm{g}^{-1}\right)$, correlated with high numbers of motile stages of this taxon $\left(76.0 \times 10^{3}\right.$ cells $\mathrm{NT}^{-1}$, see Table 4$)$. However, this species was more abundant in the motile stage of station C45 $\left(82.0 \times 10^{3}\right.$ cells NT ${ }^{-1}$, see Table 4 ) and no clear relation was observed with the cyst abundance $\left(0.9 \times 10^{3}\right.$ cysts $\left.^{-1}\right)$. It is necessary to consider that the water-column analysis of planktonic communities are only temporal snapshots whereas sediment assemblages reflect an average of cysts produced by surface communities over time (Matthiessen et al., 2005). Other factors, such as granulometry and accumulation rate of bottom sediments, need to be taken into account. Dinocysts are comparable in size to medium-coarse silt particles and their hydrodynamic behavior is similar to that of other small sedimentary particles and thus become selectively concentrated in fine-grained sediments (Tyson, 1995). Previous work has demonstrated that the frontal regions encompass the location of peak cyst concentration and the examination of sediments underlying bloom areas indicated that the cysts seeding the bloom are not exactly within the bloom area (Tyler et al., 1982). At the Patagonian Shelf, Carreto et al. (1998b) described an important concentration of A. tamarense cysts in the tidal front localized at Valdés Peninsula.

Within the region where the motile phase forms blooms, hydrographic and sedimentary processes commonly deposit the cysts in areas of fine-grained sediment termed "seed beds". The granulometry for the analyzed sites is consistent with the spatial distribution of the sediments described by Fernández (2006) with a sand fraction in the southern coast, predominance of gravels and sands in the extreme 
south of the gulf and more content of silt and clay in the central and deeper zones. At station C45 the sediments had a coarse fraction (sand) besides a fine content (silt) whereas sediments of station C43N consisted only of a fine fraction (clay and silt). This difference could explain the order of magnitude increase of the cyst abundance at C43N. Moreover, the lowest total abundances in stations C43 and S40 (with $0.64 \times 10^{3}$ and $0.89 \times 10^{3}$ dinocysts $\mathrm{g}^{-1}$, respectively) were correlated with coarser size-grains in the sediments (sabulitic). As we do not have data of sedimentation rates for the area, we cannot directly compare cyst concentrations among sampling sites. However, the studied cyst beds in the bottom sediments of the area probably reflected concentrations over many years indicating that recurrent blooms of Gonyaulax aff. spinifera are common in the area. Another possibility is that the high abundance shows a selective deposition of cysts in the thermohaline frontal system in the mouth of the SJG. The abundance of $P$. reticulatum cysts reach a value of $0.4 \times 10^{3}$ cysts $\mathrm{g}^{-1}$ at station C43N that means twice as many than inside (station C45) or north (station P45B) of SJG. The benthic cysts recovered in this study inside and at the edge of the SJG highlighted the latent possibility for the development of local blooms of potentially toxigenic dinoflagellates.

\subsection{Phycotoxin composition and distribution in field plankton samples}

Even though the dinoflagellate bloom was dominated by Ceratium spp., which formed up to $89 \%$ of the total dinoflagellate abundance in the net haul of station C43, many other dinoflagellate taxa including toxigenic species such as A. tamarense, P. reticulatum, and D. acuminata were present at lower abundances (Table 4). Generally, the toxigenic species co-occurred with their related toxins, yet with highly varying ratios between producing species and associated toxin groups (Fig. 9B/C). This variability may be due to the generally low abundances of toxigenic species. In addition, predation among planktonic species is a common feature and thus may jeopardize the ratio of toxin producer and their toxins. However, there were less toxins detected in the larger 50$200 \mu \mathrm{m}$ and $>200 \mu \mathrm{m}$ size fractions (Table 8 ), which indicates that toxin transfer to higher trophic levels did not play an important role. However, heterotrophic and mixotrophic dinoflagellates are known for a low predator:prey size ratio (Hansen et al., 1994; Jeong et al., 2010) and thus may transfer toxins among species of the same size.

The PSP toxin profiles of all field samples consisted only of GTX-2/3, which contradicts the toxin profiles of the two strains of $A$. tamarense isolated from station C43. Both strains displayed almost identical PSP profiles consisting of approximately $41 \% \mathrm{C} 1 / 2,57 \%$ GXT1/4 and $2 \%$ NEO. This profile has been reported several times for Argentinean strains of A. tamarense (Carreto et al., 2001; Montoya et al., 2010). The fact that the field samples displayed a different toxin profile than the local A. tamarense isolates, may be due to a 3-months delay of the sample transport from Argentina to the laboratory in Germany. Apparently, during this time a conversion took place from the original toxins to GTX2/3. It is well known that the N-sulfocarbamoyl C-toxins easily cleave off the N-sulfonyl group to form GTX2/3. Interestingly, in addition to the desulfonylation of the C-toxins, $\mathrm{N}$-dehydroxylation of GTX1/4 and NEO to GTX2/3 and STX, respectively, seems to occur under higher ambient temperatures during several months' periods. However, this observation is only a first indication for such processes and has to be studied in more detail under controlled conditions.

\section{Conclusions}

Hydrographic conditions favor dinoflagellate blooms in the SJG region in general. Even though the plankton community was almost monospecific and dominated by Ceratium tripos, many other dinoflagellate taxa, including $\mathrm{HAB}$ species, were present at lower concentrations in the SJG, but were hardly detected outside the Gulf at that time. However, despite the fact that the superposition of stratified water masses favor dinoflagellate proliferation in general, the precise conditions that determine the proliferation of one or the other dinoflagellate species are not well understood. But the presence of toxigenic taxa in the water column and their cysts in the sediments of the SJG clearly indicates the potential for harmful algal blooms in this area. For this reason a better understanding of the processes leading to these dinoflagellate blooms in this highly productive area is necessary, due to the importance of the SJG region for fishery industries and marine exploitation. For a better understanding of the plankton dynamics of the SJG, more integrated studies are needed to increase the temporal data resolution for this region. More detailed sediment and cyst bed analyses, determination of sedimentation rates and drift studies on occurring blooms would complement the data presented in this study.

\section{Funding}

This work was financed by the Binational project MINCyT-BMBF (AL/11/03-ARG 11/021). Additional funding was provided in the frames of the EU project IMCONet (FP7 IRSES, action no. 319718) and the HGF (Helmholtz Association of German Research Centres) through the research programme PACES. C.M.B. was supported by PIP CONICET 11420100100234 and G.O.A. and M.E.F. were supported by PIP CONICET 11420100100173.

\section{Acknowledgments}

Florian Pfaff (AWI) for sampling nutrients, Gustavo A. Lovrich (CADIC) scientific lead of the expedition Patagonia Austral of the $R / V$ Puerto Deseado (CONICET-MINDEF, Argentina), Gustavo Cano (INIDEP) for providing CTD data, the $R / V$ Puerto Deseado crew for their assistance, A. Piola (Servicio de Hidrografía Naval) for bibliographical assistance with hydrographic information and two anonymous referees for their detailed comments and suggestions, which helped to improve the manuscript.

\section{References}

Acha, E.M., Mianzan, H.W., Guerrero, R.A., Favero, M., Brava, J., 2004. Marine fronts at the continental shelves of austral South America. Physical and ecological processes. J. Mar. Syst. 44, 83-105.

Akselman, R., 1987. Quistes planctónicos de dinofíceas en áreas de plataforma del Atlántico Sudoccidental, I, Reporte taxonómico de la familia Peridiniaceae Ehrenberg. Bol. Inst. Oceanogr. 35, 17-32.

Akselman, R., 1996. Estudios ecológicos en el Golfo San Jorge y adyacencias (Atlántico sudoccidental). (Tesis Doctoral), Distribución, abundancia y variación estacional de fitoplancton en relación a factores físico-químicos y a la dinámica hidrográfica. Universidad de Buenos Aires, Buenos Aires, Argentina (234 pp.).

Akselman, R, 1999. Abundancia y distribución temporal de quistes de reposo de dinoflagelados recientes de una Estación Fija en la plataforma frente a Mar de Plata, Argentina. $3^{\circ}$ Congreso Latinoamericano sobre Ciencias del Mar, Trujillo, Perú. Libro de resúmenes ampliados 1, pp. 323-324.

Alder, V.A., Franzosi, C., 2004. Abundancia del picoplancton en el Mar Argentino y el Océano Antártico durante el verano austral. 2004. Actas del Vº Simposio Argentino y I ${ }^{\circ}$ Latinoamericano sobre Investigaciones Antárticas CD-ROM. Resumen Expandido $\mathrm{N}^{\circ}$ 204BZ. Argentina, Buenos Aires, p. 4.

Almandoz, G.O., Hernando, M.P., Ferreyra, G.A., Schloss, I.R., Ferrario, M.E., 2011. Seasonal phytoplankton dynamics in extreme southern South America (Beagle Channel Argentina). J. Sea Res. 66, 47-57.

Baldoni, A., 1990. Renovación del agua de fondo del golfo San Jorge. Tesis de Grado. Instituto Tecnológico de Buenos Aires, Buenos Aires, Argentina (37 pp.).

Bertolotti, M.I., Brunetti, N.E., Carreto, J.I., Prenzki, L.B., Sanchez, R.P., 1996. Influence of Shelf-break Fronts on Shellfish and Fish Stocks off Argentina. International Council for the Exploration of the Sea, CM (1996/S:41, 23 pp).

Bianchi, A., Masonneau, M., Oliviera, O., 1982. Análisis estadístico de las características T-S del sector austral de la plataforma continental argentina. Acta Oceanogr. Argent. 3, 93-118.

Bianchi, A.A., Bianucci, L., Piola, A.R., Ruiz Pino, D., Schloss, I., Poisson, A., Balestrini, C.F., 2005 Vertical stratification and air-sea $\mathrm{CO}_{2}$ fluxes in the Patagonian shelf. J. Geophys. Res. 110, c07003. http://dx.doi.org/10.1029/2004jc002488.

Blackburn, S.I., Hallegraeff, G.M., Bolch, C.H.J., 1989. Vegetative reproduction and sexual life cycle of the toxic dinoflagellate Gymnodinium catenatum from Tasmania Australia. J. Phycol. 25, 577-590.

Borel, C.M., Krock, B., Barrera, F.M., Tillmann, U., Gómez, E.A., Lara, R.J., 2012. Registro sedimentario de quistes de dinoflagelados de pared orgánica en EL Rincón, Atlántico Sudoccidental. Argentina. VIII Jornadas Nacionales de Ciencias del Mar - XVI Coloquio de Oceanografía, Comodoro Rivadavia, Argentina. 
Brandhorst, W., Castello, J.P., 1971. Evaluación de los recursos de anchoíta (Engraulis anchoita) frente a la Argentina y Uruguay. Serie de Informaciones Técnicas. 29. Proy. Des. Pesquero (FAO) (63 pp.).

Brandini, F.P., Boltovskoy, D., Piola, A.R., Kocmur, S., Rottgers, R., Abreu, P.C., Mendes Lopes, R., 2000. Multiannual trends in fronts and distribution of nutrients and chlorophyll in the southwestern Atlantic (30-62S). Deep Sea Res. I 47, 1015-1033.

Bravo, I., Figueroa, R.I., 2014. Towards an ecological understanding of dinoflagellate cyst functions. Microorganisms 2, 11-32.

Carreto, J.I., Negri, R.M., Benavides, H.R., Akselman, R., 1985. Toxic dinoflagellate blooms in the Argentine Sea. In: Anderson, White, Baden (Eds.), Toxic dinoflagellates. Elsevier Sci. Publ. Co, N. Y, pp. 147-152.

Carreto, J.I., Benavides, H.R., Negri, R.M., Glorioso, P.D., 1986. Toxic Red tide in the Argentine Sea. Phytoplankton distribution and survival of the toxic dinoflagellate Gonyaulax excavata in a frontal area. J. Plankton Res. 8, 15-28.

Carreto, J.I., Akselman, R., Montoya, N.G., Negri, R.M., Benavides, H.R., Carignan, M.O.D. Cucchi Colleoni, A.D.C., 1998a. Alexandrium tamarense bloom dynamics and Mytilus edulis toxicity in the coastal waters off Mar del Plata (Argentina). In: Blanco, J. Fernández, M.L., Wyatt, T., Reguera, B. (Eds.), Harmful Algae. Xunta de Galicia and Intergovernmental Oceanographic Commission of UNESCO, pp. 135-138.

Carreto, J.I., Montoya, N.G., Colleoni, A.D.C., Akselman, R., 1998b. Alexandrium tamarense blooms and shellfish toxicity in the Argentine Sea: a retrospective view. In: Reguera, B., Blanco, J., Fernandez, M.L., Wyatt, T. (Eds.), Harmful Algae. Xunta de Galicia and IOC/UNESCO, pp. 131-134.

Carreto, J.I., Carignan, M.O., Montoya, N.G., 2001. Comparative studies on mycosporine-like amino acids, paralytic shellfish toxins and pigment profiles of the toxic dinoflagellates Alexandrium tamarense, A. catenella and A. minutum. Mar. Ecol. Prog. Ser. 223, 49-60.

Carreto, J.I., Montoya, N.G., Carignan, M.O., 2008. Floraciones de algas tóxicas. In: Boltovskoy, D. (Ed.), Atlas de Sensibilidad Ambiental de la Costa y el Mar Argentino. Secretaría de Ambiente y Desarrollo Sustentable, Buenos Aires, pp. 1-11.

Cullen, J.J., Horrigan, S.G., 1981. Effects of nitrate on the diurnal vertical migration, carbon to nitrogen ratio, and the photosynthetic capacity of the dinoflagellate Gymnodinium splendens. Mar. Biol. 62, 81-89.

Dale, B., 2001. The sedimentary record of dinoflagellate cysts: looking back into the future of phytoplankton blooms. Sci. Mar. 65, 257-272.

De Vernal, A., Marret, F., 2007. Organic-walled dinoflagellate cysts: tracers of sea-surface conditions. In: Hillaire-Marcel, C., De Vernal, A. (Eds.), Proxies in Late Cenozoic Paleoceanography. Developments in Marine Geology vol. 1. Elsevier, Amsterdam, pp. 371-400.

De Vernal, A., Henry, M., Bilodeau, G., 1996. Micropaleontological preparation techniques and analyses. Les Cahiers du Geotop. 3. Département des Sciences de la Terre, UQAM (32 pp.).

Eppley, R.W., Holm-Hansen, O., Strickland, J.D.H., 1968. Some observations on the vertical migration of dinoflagellates. J. Phycol. 4, 333-340.

Esteves, J.L., Santinelli, N., Sastre, V.R., Diaz, R., Rivas, O., 1992. A toxic dinoflagellate bloom and PSP production associated with upwelling in Golfo Nuevo, Patagonia Argentina. Hydrobiologia 242, 115-122.

Fensome, R.A., Taylor, F.J.R., Norris, G., Sarjeant, W.A.S., Wharton, D.I., Williams, G.L., 1993. A classification of fossil and living dinoflagellates. Micropaleontol. Press Spec. Pap. 7 (351 pp. New York)

Fernández, M., 2006. Características físico-químicas de los sedimentos del Golfo San Jorge y su relación con los organismos bentónicos del sector. (PhD Thesis), Universidad Nacional de Mar del Plata (308 pp.)

Fernández, M., Cucchi Colleoni, D., Roux, A., Marcos, A., Fernández, E., 2007. Physicochemical characterization of the benthic system in the south area of the San Jorge Gulf, Argentina. Rev. Biol. Mar. Oceanogr. 42, 177-192.

Figueroa, R.I., Rengefors, K., Bravo, I., 2006. Effects of parental factors and meiosis on sexual offspring of Gymnodinium nolleri (Dinophyceae). J. Phycol. 42, 350-362.

Fritz, L., Triemer, R.E., 1985. A rapid simple technique utilizing Calcofluor white M2R for the visualization of dinoflagellate thecal plates. J. Phycol. 21, 662-664.

Garcia, V.M.T., Garcia, C.A.E., Mata, M.M., Pollery, R.C., Piola, A.R., Signorini, S.R. McClain, C.R., Iglesias-Rodriguez, M.D., 2008. Environmental factors controlling the phytoplankton blooms at the Patagonia shelf-break in spring. Deep Sea Res. I 55, $1150-1166$.

Gargett, E., 1997. The optimal stability 'window': a mechanism underlying decadal fluctuations in North Pacific salmon stocks? Fish. Oceanogr. 6, 109-117.

Genovesi-Giunti, B., Laabir, M., Vaquer, A., 2006. The benthic resting cyst: a key actor in harmful dinoflagellate blooms: a review. Vie Milieu 56, 327-337.

Glorioso, P.D., Flather, R.A., 1997. The Patagonia shelf tides. Prog. Oceanogr. 40, 263-283.

Gómez, M.I., Piola, A.R., Kattner, G., Alder, V.A., 2011. Biomass of autotrophic dinoflagellates under weak vertical stratification and contrasting chlorophyll levels in subantarctic shelf waters. J. Plankton Res. 33, 1304-1310.

Guerrero, R., Piola, A.R., 1997. Masas de agua en la Plataforma Continental. In: Boschi, E. (Ed.), El mar argentino y sus recursos pesqueros. Antecedentes históricos de las exploraciones en el mar y las características ambientales. vol. 1. Publicaciones Especiales INIDEP, Mar del Plata, Argentina, pp. 107-118.

Hallegraeff, G.M., Marshall, J.A., Valentine, J., Hardiman, S., 1998. Short cyst-dormancy period of an Australian isolate of the toxic dinoflagellate Alexandrium catenella. Mar. Freshw. Res. 49, 415-420.

Hansen, B., Bjornsen, P.K., Hansen, P.J., 1994. The size ration between planktonic predators and their prey. Limnol. Oceanogr. 39, 395-403.

Head, M.J., 1996. Modern dinoflagellate cysts and their biological affinities. In: Jansonius, J., McGregor, D.C. (Eds.), Palynology: Principles and Applications. American Association of Stratigraphic Palynologists Foundation, Dallas, Texas, pp. 1197-1248.

Head, M., Lewis, J., De Vernal, A., 2006. The cyst of the calcareous dinoflagellate Scrippsiella trifida: resolving the fossil record of its organic wall with that of Alexandrium tamarense. J. Paleontol. 80, 1-18.
Holm-Hansen, O., Lorenzen, C.J., Holmes, R.W., Strickland, J.D.H., 1965. Fluorometric determination of chlorophyll. J. Cons. Int. Explor. Mer 30, 3-15.

Jeong, H.J., Yoo, Y.D., Kim, J.S., Seong, K.A., Kang, N.S., Kim, T.H., 2010. Growth, feeding, and ecological roles of the mixotrophic and heterotrophic dinoflagellates in marine planktonic food webs. Ocean Sci. J. 45, 65-91.

Ji, R., Franks, P.J.S., 2007. Vertical migration of dinoflagellates: model analysis of strategies, growth, and vertical distribution patterns. Mar. Ecol. Prog. Ser. 344, 49-61.

Kattner, G., 1999. Storage of dissolved inorganic nutrients in seawater: poisoning with mercuric chloride. Mar. Chem. 67, 61-66.

Kattner, G., Becker, H., 1991. Nutrients and organic nitrogenous compounds in the marginal ice zone of the Fram Strait. J. Mar. Syst. 2, 385-394.

Keller, M.D., Selvin, R.C., Claus, W., Guillard, R.R.L., 1987. Media for the culture of oceanic ultraphytoplankton. J. Phycol. 23, 633-638.

Kremp, A., Anderson, D.M., 2000. Factors regulating germination of resting cysts of the spring bloom dinolfagellate Scrippsiella hangoei from the northern Baltic Sea. J. Plankton Res. 22, 1311-1327.

Krock, B., Seguel, C.G., Cembella, A.D., 2007. Toxin profile of Alexandrium catenella from the Chilean coast as determined by liquid chromatography with fluorescence detection and liquid chromatography coupled with tandem mass spectrometry. Harmful Algae 6, 734-744

Krock, B., Tillmann, U., Selwood, A.I., Cembella, A.D., 2008. Unambiguous identification of pectenotoxin-1 and distribution of pectenotoxins in plankton from the North Sea. Toxicon 52, 927-935

Krock, B., Tillmann, U., John, U., Cembella, A.D., 2009. Characterization of azaspiracids in plankton size-fractions and isolation of an azaspiracid-producing dinoflagellate from the North Sea. Harmful Algae 8 (2), 254-263.

Lara, R.J., Alder, V., Franzosi, C.A., Kattner, G., 2010. Characteristics of suspended particulate organic matter in the southwestern Atlantic: influence of temperature, nutrient and phytoplankton features on the stable isotope signature. J. Mar. Syst. 79, 199-209.

LeGresley, M., McDermott, G., 2010. Counting chamber methods for quantitative phytoplankton analysis - haemocytometer, Palmer-Maloney cell and Sedgewick-Rafter cell. In: Karlson, B., Cusack, C., Bresnan, E. (Eds.), Microscopic and molecular methods for quantitative phytoplankton analysis. UNESCO, Paris (IOC Manuals and Guides, no. 55.).

Lilly, E.L., Halanych, K.M., Anderson, D.M., 2007. Species boundaries and global biogeography of the Alexandrium tamarense species complex. J. Phycol. 43, 1329-1338.

Lutz, V.A., Segura, V., Dogliotti, A.I., Gagliardini, D.A., Bianchi, A.A., Balestrini, C.F., 2010. Primary production in the Argentine Sea during spring estimated by field and satellite models. J. Plankton Res. 32, 181-195.

Marie, D., Simon, N., Vaulot, D., 2005. Phytoplankton cell counting by flow cytometry. In: Andersen, R.A. (Ed.), Algal Culturing Techniques. Elsevier, Amsterdam, The Netherlands, pp. 253-267.

Martos, P., Sánchez, R.P., 1997. Caracterización oceanográfica de regiones frontales en la plataforma patagónica en relación con áreas de desove y cría de anchoita (Engraulis anchoita). Abstracts Coloquio Argentino de Oceanografía. IAPSO-IADO (CONICET), Bahía Blanca, Argentina, 4-5 September 1997, p. 30.

Matano, R.P., Palma, E.D., Piola, A.R., 2010. The influence of the Brazil and Malvinas currents on the Southwestern Atlantic Shelf circulation. Ocean Sci. 6, 983-995.

Matsuoka, K., Fukuyo, Y., 2000. Technical Guide for Modern Dinoflagellate Cyst Study. WESTPAC-HAB/WESTPAC/IOC, Japan Society for the Promotion of Science, Tokyo $29 \mathrm{pp}$.

Matsuoka, K., Head, M.J., 2013. Clarifying cyst-motile stage relationships in dinoflagellates. In: Lewis, JM. Marret, F. Bradley, L (Eds.), Biological and Geological Perspectives of Dinoflagellates. The Micropaleontological Society, Special Publications. Geological Society, London.

Matthiessen, J., De Vernal, A., Head, M., Okolodkov, Y., Zonneveld, K., Harland, R., 2005. Modern organic-walled dinoflagellate cysts in Arctic marine environments and their (paleo-) environmental significance. Paläontol. Z. 79, 3-51.

Mayali, X., Franks, P.J.S., Azam, F., 2007. Bacterial induction of temporary cyst formation by the dinoflagellate Lingulodinium polyedrum. Microb. Ecol. 50, 51-62.

McQuoid, M.R., Godhe, A., Nordberg, K., 2002. Viability of phytoplankton resting stages in the sediments of a coastal Swedish fjord. Eur. J. Phycol. 37, 191-201.

Montoya, N.G., Negri, R.M., Carignan, M.O., Carreto, J.I., 2006. Some biochemical characteristics of toxic diatom Pseudo-nitzschia multiseries isolated in the Argentine Sea. Anais do XI Congresso Brasileiro de Ficologia e Simpósio Latino-Americano sobre Algas Nocivas, Organização da Sociedade Brasileira de Ficologia, Universidade do Vale do Itajai, 25 de março a 01 de abril de 2006, pp. 259-266.

Montoya, N.G., Fulco, V.K., Carignan, M.O., Carreto, J.I., 2010. Toxin variability in cultured and natural populations of Alexandrium tamarense from southern South America evidences of diversity and environmental regulation. Toxicon 56, 1408-1418.

Negri, R.M., Montoya, N.G., Carreto, J.I., Akselman, R., Inza, D., 2004. Pseudo-nitzschia australis, Mytilus edulis, Engraulis anchoita, and domoic acid in the Argentine Sea. In: Steidinguer, K.A., Landsberg, J.H., Tomas, C.R., Vargo, G.A. (Eds.), Harmful Algae 2002. Florida Fish and Wildlife Conservation Comission, Florida Institute of Oceanography, and Intergovernamental Oceanographic Comission of UNESCO, St. Petesbourg, Florida, USA, pp. 139-141.

Orozco, F.E., Carreto, J.I., 1989. Distribution of Alexandrium excavatum cyst in a Patagonic area (Argentina). In: Okaichi, T., Anderson, D.M., Nemoro, T. (Eds.), Red Tides: Biology, Environmental Science and Toxicology. Elsevier Science Publishing, pp. 309-312.

Palma, E.D., Matano, R.P., Piola, A.R., 2004. A numerical study of the Southwestern Atlantic Shelf circulation: barotropic response to tidal and wind forcing. J. Geophys. Res. 109, C08014. http://dx.doi.org/10.1029/ 2004JC002315.

Park, M.G., Kim, S., Kim, H.S., Myung, G., Kang, Y.G., Yih, W., 2006. First successful culture of the marine dinoflagellate Dinophysis acuminata. Aquat. Microb. Ecol. 45, 101-106. 
Piola, A.R., Rivas, A.L., 1997. Corrientes en la plataforma continental. In: Boschi, E.E. (Ed.) En: El Mar Argentino y sus recursos pesqueros. Tomo 1. Antecedentes históricos de las exploraciones en el mar y las características ambientales. INIDEP, Mar del Plata, Argentina, pp. 119-132.

Piola, A.R., Martínez, Avellaneda N., Guerrero, R.A., Jardón, F.P., Palma, E.D., Romero, S.I., 2010. Malvinas-slope water intrusions on the northern Patagonia continental shelf. Ocean Sci. 6, 345-359.

Piola, A.R., Franco, B.C., Palma, E.D., Saraceno, M., 2013. Multiple jets in the Malvinas Current. J. Geophys. Res. Oceans 118, 2107-2117.

Ribeiro, S., Berge, T., Lundholm, N., Andersen, T., Abrantes, F., Ellegaard, M., 2011. Phytoplankton growth after a century of dormancy illuminates past resilience to catastrophic darkness. Nat. Commun. 2, 311. http://dx.doi.org/10.1038/ncomms1314.

Rivas, A.L., Pisoni, J.P., 2010. Identification, characteristics and seasonal evolution of surface thermal fronts in the Argentinean Continental Shelf. J. Mar. Syst. 79, 134-143.

Rivas, A.L., Dogliotti, A.I., Gagliardini, D.A., 2006. Seasonal variability in satellite-measured surface chlorophyll in the Patagonian Shelf. Cont. Shelf Res. 26, 703-720.

Rochon, A., Lewis, J., Ellegaard, M., Harding, I.C., 2009. The Gonyaulax spinifera (Dinophyceae) "complex": Perpetuating the paradox? Rev. Palaeobot. Palynol. 155, 52-60.

Romero, S.I., Piola, A.R., Charo, M., Garcia, C.A.E., 2006. Chlorophyll a variability off Patagonia based on SeaWiFS data. J. Geophys. Res. 111, C05021. http://dx.doi.org/10.1029/ 2005JC003244.

Sabatini, M.E., Ramírez, F.C., Martos, P., 2000. Distribution pattern and population structure of Calanus australis Brodsky, 1959 over the southern Patagonian Shelf off Argentina in summer. ICES J. Mar. Sci. 57, 1856-1866.

Sabatini, M.E., Reta, R., Matano, R., 2004. Circulation and zooplankton biomass distribution over the southern Patagonian shelf during late summer. Cont. Shelf Res. 24, 1359-1373.

Santinelli, N., Sastre, V., Esteves, J.L., 2002. Episodios de algas nocivas en la Patagonia Argentina. In: Sar, E.A., Ferrario, M.E., Reguera, B. (Eds.), Floraciones Algales Nocivas en el Cono Sur Americano. Instituto Español Oceanográfico de Madrid, Vigo, pp. 199-208.

Sar, E.A., Sunesen, I., Lavigne, A.S., Goya, A.B., 2010. Dinophysis spp. asociadas a detección de toxinas diarreicas en moluscos (DSTs) y a intoxicación diarreica en humanos (Provincia de Buenos Aires, Argentina). Rev. Biol. Mar. Oceanogr. 45, 451-460.
Sar, E.A., Sunesen, I., Goya, A.B., Lavigne, A.S., García, C., Lagos, N., 2012. First report of Diarrhetic Shellfish Toxins in molluscs from Buenos Aires Province (Argentina) associated to Dinophysis spp.: Evidence of Okadaic acid, Dinophysistoxin-1 and Acylderivatives. Bol. Soc. Argent. Bot. 47, 5-14.

Sastre, A., Santinelli, N., Marino, G., Solís, M., Pujato, L., Ferrario, M.E., 2007. First detection of domoic acid produced by Pseudo-nitzschia species, Chubut coastal waters, Patagonia, Argentina. Harmful Algae News 34, 12-14.

Sherr, E.B., Sherr, B.F., 2007. Heterotrophic dinoflagellates: a significant component of microzooplankton biomass and major grazers of diatoms in the sea. Mar. Ecol. Prog. Ser. 352, 187-197.

Schlitzer, R., 2010. Ocean Data View. http://odv.awi.de.

Simpson, J.H., 1981. The shelfesea fronts: implications of their existence and behaviour. Phil. Trans. Roy. Soc. London A 302, 531-546.

Smayda, T.J., 1997. Harmful algal blooms: their ecophysiology and general relevance to phytoplankton blooms in the sea. Limnol. Oceanogr. 42, 1137-1153.

Stockmarr, J., 1971. Tablets with spores used in absolute pollen analysis. Pollen Spores 13, 615-621.

Taylor, F.J.R., Pollingher, U., 1987. Ecology of dinoflagellates. In: Taylor, F.J.R. (Ed.), The Biology of Dinoflagellates. Blackwell Scientific Publicaitons, Oxford, pp. 1-23.

Tonini, M., Palma, E.D., Rivas, A.L., 2006. Modelo de alta resolución de los Golfos Patagonicos. Mecánica Computacional vol. XXV pp. 1441-1460.

Tyler, M.A. Coats, D.W. Anderson, D.M. 1982. Encystment in a dynamic environment: deposition of dinoflagellate cysts by a frontal convergence. Mar. Ecol. Prog. Ser. 7 163-178.

Tyson, R.V., 1995. Sedimentary Organic Matter. Organic Facies and Palynofacies. Chapman and Hall, London, p. 615.

Utermöhl, H., 1958. Zur Vervollkommnung der quantitativen Phytoplanktonmethodik. Mitt. Int. Ver. Theor. Angew. Limnol. 9, 1-38.

Wall, D., Dale, B., Lohmann, G., Smith, W., 1977. The environmental and climatic distribution of dinoflagellate cysts in modern marine sediments from regions in the North and South Atlantic Ocean and adjacent seas. Mar. Micropaleontol. 2, 121-200.

Warns, A., Hense, I., Kremp, A., 2012. Modelling the life cycle of dinoflagellates: a case study with Biecheleria baltica. J. Plankton Res. 35, 379-392. 